\title{
Production and turnover of particulate dimethylsulphoniopropionate during a coccolithophore bloom in the northern North Sea
}

\author{
Stephen D. Archer*, Claire E. Widdicombe, Glen A. Tarran, Andrew P. Rees, \\ Peter H. Burkill
}

Plymouth Marine Laboratory, Prospect Place, Plymouth PL1 3DH, United Kingdom

\begin{abstract}
Dimethylsulphoniopropionate (DMSP) synthesised by phytoplankton is the principal precursor of the climatically active gas dimethyl sulphide (DMS). The rates of production of particulate DMSP (DMSPp) and turnover by microzooplankton were determined in surface waters of the northern North Sea, using a dilution approach. The phytoplankton communities were characterised by DMSPrich taxa including Emiliania huxleyi and Prorocentrum minimum and DMSPp:chlorophyll a (chl a) ratios of 64 to $162 \mathrm{nM} \mathrm{\mu g}^{-1}$. Microzooplankton biomass varied from 25.5 to $56.7 \mathrm{\mu g} \mathrm{Cl}^{-1}$ and was dominated by oligotrich ciliates and heterotrophic dinoflagellates. DMSPp production rates ranged from 14.8 to $45.6 \mathrm{nM} \mathrm{d}^{-1}$ and represent a doubling time of the ambient DMSPp pool of between 1.2 and $3.1 \mathrm{~d}$. Consumption rates of DMSPp by microzooplankton varied between 11.4 and $59.9 \mathrm{nM} \mathrm{d}^{-1}$ and were equivalent to turnover rates of the ambient DMSPp pool of between 16 and $43 \% \mathrm{~d}^{-1}$. In general, production rates of DMSPp were lower than those of chl a and E. huxleyi, with respective mean doubling times of 1.9, 1.5 and $1.3 \mathrm{~d}$. Loss rates due to grazing were similar for DMSPp and E. huxleyi but generally significantly lower than those of the bulk phytoplankton, with mean turnover rates of 31,30 and $40 \% \mathrm{~d}^{-1}$ of the standing stock of DMSPp, E. huxleyi and chl $a$, respectively. E. huxleyi contributed an estimated 2 to $25 \%$ of the total DMSPp production and 6 to $23 \%$ of the DMSPp ingested by microzooplankton, indicating the importance of other phytoplankton to DMSPp dynamics in 'E. huxleyi blooms'. At the depths sampled, DMSPp production was closely coupled to primary production and was equivalent to approximately $11 \%$ of the carbon fixation. DMSPp may be an important component of the diets of microzooplankton. Ingested DMSPp could have provided 2 to $3 \%$ of the microzooplankton carbon demand and 26 to $44 \%$ of their sulphur demand. DMSPp production and turnover rates were closely matched and suggest that in these waters microzooplankton grazing may be the principal determinant of the fate of DMSPp. The quantity of 'DMSP' excreted by microzooplankton, calculated from ingestion rates, biomass and assumed growth rates and growth efficiencies, ranged from 8.0 to $41.9 \mathrm{nM} \mathrm{d}^{-1}$. This is equivalent to 13 to $35 \% \mathrm{~d}^{-1}$ of the DMSPp standing stocks and sufficient to support a daily turnover of the DMS plus dissolved DMSP (DMS+DMSPd) pool.
\end{abstract}

KEY WORDS: Dimethylsulphoniopropionate (DMSP) $\cdot$ Production rate $\cdot$ Grazing rate $\cdot$ Emiliania huxleyi $\cdot$ microzooplankton · Dimethyl sulphide (DMS) · North Sea

\section{INTRODUCTION}

Dimethylsulphoniopropionate (DMSP) is an organic sulphur compound synthesised by marine micro- and macroalgae and a small number of higher plants. A

*E-mail: stda@pml.ac.uk great deal of interest in DMSP stems from the fact that it is the principal precursor of dimethyl sulphide (DMS) in the oceans. Marine emissions of DMS amount to more than half the natural flux of sulphur to the atmosphere (Andreae \& Crutzen 1997). Once in the atmosphere, DMS is oxidised to sulphuric acid and methanesulphonate, forming sub-micrometer particles that scatter solar radiation and may act as cloud condensa- 
tion nuclei affecting cloud radiative transfer and hence climate (Charlson et al. 1987, Ayers \& Gras 1991). One of the keys to understanding the links between biogenic DMS production and climate is to discern the processes that control DMS concentrations in seawater (Liss et al. 1997). This is known to involve a multitude of interactive biological, chemical and physical processes. Of central importance is the rate at which phytoplankton produce DMSP and the fate of that production.

DMSP may make a substantial contribution to the organic sulphur (50 to $100 \%$ ) and organic carbon content $(>10 \%)$ of DMSP-rich micro-algae (Matrai \& Keller 1994). Why phytoplankton produce DMSP is not entirely clear and several physiological roles have been suggested (reviewed in Stefels 2000). The most commonly held view is that DMSP, along with a number of other compounds, acts as a compatible solute in cells (Viaravamurthy et al. 1985, Dickson \& Kirst 1987a,b, Kirst 1996). In a similar osmotic role, DMSP may act as a cryoprotectant, and high concentrations have been recorded in polar macroalgae (Karsten et al. 1992) and in sea-ice micro-algae (Kirst et al. 1991, Trevena et al. 2000). DMSP synthesis in marine microalgae is thought to proceed via 1 of 3 elucidated pathways from methionine and involves transamination, reduction, S-methylation and oxidative decarboxylation steps (Gage et al. 1997). Stefels (2000) proposed that DMSP may be a by-product of the metabolic regulation of the sulphur containing amino acids cysteine and methionine. DMSP may be employed as a methyl donor in biological transmethylation reactions (Ishida 1996 and references therein) and may be a precursor in the biosynthesis of the membrane phospholipid phosphatidylsulphocholine in marine micro-algae (Kates \& Volcani 1996). In addition, DMSP is thought to have a role as a grazing deterrent when ingestion or digestion of phytoplankton by grazers results in its enzymatic cleavage to DMS and acrylate (Wolfe \& Steinke 1996). Perhaps because of this variety of roles, there is considerable interspecific variability in the intracellular concentrations of DMSP in phytoplankton (Keller et al. 1989). The distributions of particulate DMSP (DMSPp) in natural waters are thought to reflect these differences, with particularly high concentrations correlated with the abundance of the prymnesiophytes Phaeocystis sp. and Emiliania huxleyi and with a variety of dinoflagellates (e.g. Barnard et al. 1984, Holligan et al. 1987, Turner et al. 1988, 1996, Malin et al. 1993, Matrai \& Keller 1993).

Predictive models of DMS emission have progressed from using a single DMSP:phytoplankton biomass quota to determine DMSP production rates (Gabric et al. 1993) to ascribing different DMSP quotas to differing components of the phytoplankton (van den Berg
1996) and, further, to using varying cell-specific DMSP synthesis rates in relation to the growth phase of the phytoplankton bloom (Laroche et al. 1999). Direct estimates of DMSPp production in natural waters are scarce. At a time series station in the northeastern Pacific, Bates et al. (1994) spiked water samples with ${ }^{35} \mathrm{SO}_{4}{ }^{2-}$ and determined the incorporation rate of radiolabel into non-protein reduced sulphur, which would include DMSP-sulphur. During a Lagrangian experiment in the Iceland Basin, Simó \& Pedrós-Alió (1999) were able to estimate a total (particulate+dissolved) DMSP production rate from measurements of DMSP consumption (calculated as the decrease in total DMSP in bottles incubated in the dark) and in situ net DMSP production between sampling dates.

Processes that typically control the fate of primary production also control the fate of DMSPp, including its transformation to dissolved DMSP (DMSPd) and DMS. Actively growing phytoplankton cells appear to excrete little DMS or DMSPd, and seawater concentrations of DMS are often poorly correlated to the biomass of phytoplankton (e.g. Leck et al. 1990, Dacey et al. 1998). However, enhanced DMSP exudation does result from phytoplankton senescence and has been linked to nutrient deficiency (Nguyen et al. 1988) and cell sedimentation (Osinga et al. 1996). Viral lysis of phytoplankton results in the release of DMSP in laboratory cultures (Hill et al. 1998, Malin et al. 1998), and viruses are known to affect the productivity of blooms of DMSP-rich Emiliania huxleyi in natural waters (Bratbak et al. 1996). Laboratory studies have shown that grazing by copepods on dinoflagellates and by protozoans on prymnesiophytes enhances DMS production (Dacey \& Wakeham 1986, Malin et al. 1994, Christaki et al. 1996, Wolfe \& Steinke 1996). In addition, several field studies have suggested that grazing is a key route by which DMSPd and DMS are produced (Belviso et al. 1990, Leck et al. 1990, Holligan et al. 1993, Christaki et al. 1996, Daly \& DiTullio 1996). However, grazing does not always result in DMS or DMSPd production (Wolfe et al. 1994, Kwint et al. 1996), and a proportion of ingested DMSPp may be assimilated by grazers either directly into their tissue (Tang et al. 1999) or to meet carbon and sulphur demand. Microzooplankton are capable of consuming 20 to $>100 \%$ of primary production each day (e.g. Gifford 1988, Burkill et al. 1993, Verity et al. 1996). Despite the potential importance of microzooplankton herbivory in determining the fate of phytoplankton DMSP and evidence that grazing transforms phytoplankton DMSP to DMS, direct estimates of the turnover of DMSPp by grazers in natural waters is limited.

One approach routinely used to estimate instantaneous growth rates of phytoplankton and turnover rates by microzooplankton is the dilution technique 
(Landry \& Hassett 1982). Generally, measurements of the changes in concentration of chlorophyll a ( $\mathrm{chl} \mathrm{a}$ ) in a series of incubations diluted to varying degrees to create a gradient of grazing pressure yield an estimate of the growth and mortality of the phytoplankton community. Modifications of the method have evolved to examine growth and mortality rates of specific components of the phytoplankton by quantifying changes in specific pigments (e.g. Burkill et al. 1987, Strom \& Welshmeyer 1991, Latasa et al. 1997) and by enumerating specific cell types (e.g. Landry et al. 1984, 1995b). In addition, the method has been used to examine rates of nitrogen uptake, regeneration and excretion (Andersen et al. 1991, Neuer \& Franks 1993, Lehrter et al. 1999). Recently, the dilution approach has been applied to estimates of DMS+DMSPd production rates due to microzooplankton grazing (Archer et al. 2001) and to examine grazing rates on DMSP versus chl $a$ in the Labrador Sea (Wolfe et al. 2000).

The specific aim of the present study was to determine a rate of production and turnover of DMSPp in surface waters containing DMSP-rich phytoplankton. The approach taken involved combining dilution experiments with measurements of DMSPp. This allowed us to closely couple microzooplankton grazing with DMSPp production and turnover. On the basis of this information we address the contribution of DMSP to grazer diets, assess the rate of transformation of DMSPp to DMS+DMSPd by grazers and estimate the proportion of primary production invested in DMSPp synthesis by phytoplankton. We demonstrate that the dilution approach can provide new insights into the production and fate of DMSPp with implications for its transformation to DMS.

\section{MATERIALS AND METHODS}

The present study formed part of a multidisciplinary programme (dimethyl sulphide biogeochemistry within a coccolithophore bloom, DISCO) aboard the
RRS 'Discovery' in June 1999. A relatively small $\left(\sim 2000 \mathrm{~km}^{2}\right)$, coherent bloom of Emiliania huxleyi was located by remote sensing of $555 \mathrm{~nm}$ backscatter and true colour images (SeaWiFS) in the Northern North Sea at approximately $58^{\circ} 56^{\prime} \mathrm{N}, 02^{\circ} 2^{\prime} \mathrm{E}$. A $3 \times 4$ mile $(4.8 \times 6.4 \mathrm{~km})$ patch of water at the southeastern edge of the bloom was labelled with sulphur hexafluoride $\left(\mathrm{SF}_{6}\right)$ to provide a Lagrangian component to the study (e.g. Law et al. 1998). Tracking and sampling of the $\mathrm{SF}_{6}$ labelled waters (Nightingale et al. 2000) continued from 17 to 24 June. Subsequently, sampling was carried out at a variety of locations within the bloom. A dilution experiment was carried out each day in which the net changes in DMSPp, chl a and abundance of specific phytoplankton were monitored. To support this information, water samples were collected to provide a detailed description of the phytoplankton and microzooplankton communities present.

Experimental set-up. The approach used for dilution experiments was based on the protocol of Landry \& Hassett (1982) and Landry et al. (1995a). The dates on which experiments were started and the location and environmental conditions of the sampled water are shown in Table 1. Initially, samples were collected from $5 \mathrm{~m}$ to coincide with the depth of maximum $\mathrm{SF}_{6}$ concentration and to sample the surface mixed layer of approximately $20 \mathrm{~m}$. However, the sampling depth was increased to $10 \mathrm{~m}$ after 23 June to account for subduction of the $\mathrm{SF}_{6}$ labelled patch beneath a 4 to $5 \mathrm{~m}$ layer of less dense water originating to the east of the bloom. Water sampling took place pre-dawn using 301 Niskin bottles with Teflon coated stainless steel springs. Prior to each experiment, filter capsules, silicon tubing and carboys were soaked in $10 \% \mathrm{HCl}-$ Milli-Q water and rinsed with Milli-Q water; the first 5 to $10 \mathrm{l}$ of filtered seawater was discarded. Seawater was gravity filtered through a $0.2 \mu \mathrm{m}$ Gelman Criticap filter into $20 \mathrm{l}$ carboys to produce 4 levels of dilution $(20,40,70$ and $100 \%$ ambient plankton densities). A second CTD cast was used to collect water from the same depth, and this was gently siphoned into each

Table 1. Position and environmental parameters of water sampled for dilution experiments. The sampling location relative to the $\mathrm{SF}_{6}$-labelled patch and the $2000 \mathrm{~km}^{2}$ Emiliania huxleyi bloom is also shown

\begin{tabular}{|lccccc|}
\hline Day in June & Position & Depth $(\mathrm{m})$ & Temperature $\left({ }^{\circ} \mathrm{C}\right)$ & Salinity (PSU) & Location \\
\hline 18 & $58^{\circ} 52.6^{\prime} \mathrm{N}, 03^{\circ} 03.0^{\prime} \mathrm{E}$ & 5 & 11.6 & 35.007 & Lagrangian patch \\
19 & $58^{\circ} 495^{\prime} \mathrm{N}, 03^{\circ} 12.8^{\prime} \mathrm{E}$ & 5 & 11.6 & 35.041 & Lagrangian patch \\
21 & $58^{\circ} 368^{\prime} \mathrm{N}, 03^{\circ} 30.9^{\prime} \mathrm{E}$ & 5 & 11.3 & 35.002 & Lagrangian patch \\
22 & $58^{\circ} 308^{\prime} \mathrm{N}, 03^{\circ} 30.4^{\prime} \mathrm{E}$ & 5 & 11.5 & 34.817 & Lagrangian patch \\
24 & $58^{\circ} 205^{\prime} \mathrm{N}, 03^{\circ} 28.4^{\prime} \mathrm{E}$ & 10 & 11.2 & 35.030 & SE edge of bloom \\
26 & $58^{\circ} 152^{\prime} \mathrm{N}, 03^{\circ} 33.7^{\prime} \mathrm{E}$ & 11 & 11.2 & 35.085 & SE edge of bloom \\
27 & $58^{\circ} 468^{\prime} \mathrm{N}, 02^{\circ} 40.1^{\prime} \mathrm{E}$ & 11 & 11.6 & 35.135 & Bloom centre \\
28 & $58^{\circ} 42.0^{\prime} \mathrm{N}, 02^{\circ} 30.6^{\prime} \mathrm{E}$ & 11 & 12.3 & 34.998 & S edge of bloom \\
\hline
\end{tabular}


carboy through a $200 \mu \mathrm{m}$ mesh bag to remove mesozooplankton. The experimental water from each carboy was then siphoned into triplicate 2.31 polycarbonate bottles and nutrients added to each bottle. Nitrate $\left(\mathrm{NaNO}_{3}\right)$, ammonium $\left(\mathrm{NH}_{4} \mathrm{Cl}\right)$, phosphate $\left(\mathrm{K}_{2} \mathrm{HPO}_{4}\right.$. $\left.3 \mathrm{H}_{2} \mathrm{O}\right)$ and silicate $\left(\mathrm{Na}_{2} \mathrm{SiO}_{3} \cdot 5 \mathrm{H}_{2} \mathrm{O}\right)$ were added to produce a final concentration of added nutrients in each incubation bottle of $17.4 \mathrm{nM}$ for the first 4 experiments. This was reduced to $8.7 \mathrm{nM}$ for the final 4 experiments as nutrient levels decreased in the sampled waters. Three bottles containing undiluted water without nutrient enrichment were used as natural seawater controls. Incubations were carried out in a flowthrough on-deck incubator for $24 \mathrm{~h}$. Incubators were covered with a neutral density filter and 2 sheets of Perspex to simulate either $55 \%$ (5 m samples) or $33 \%$ (10 m samples) PAR (photosynthetically active radiation, 400 to $700 \mathrm{~nm})$. Initial $\left(T_{0}\right)$ concentrations of DMSPp, chl $a$ and the abundance of Emiliania huxleyi were determined from triplicate subsamples taken from the 4 carboys. Final $\left(T_{24}\right)$ concentrations were measured from each incubation bottle.

DMSP and DMS analyses. A cryogenic purge-andtrap/gas chromatography (GC) system similar to that described by Turner et al. (1990) was used to determine DMS concentrations. A Varian 3800 gas chromatograph equipped with a pulsed flame photometric detector (PFPD) was used to analyse all samples. The analytical column used was a $30 \mathrm{~m} \times 0.53 \mathrm{~mm}$ CP Sil 5CB from Chrompack and was operated isothermally at $60^{\circ} \mathrm{C}$. Nitrogen was the carrier gas at a flow rate of

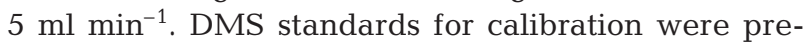
pared from DMSP-HCl (>98\% purity, CASS, University of Groningen) in Milli-Q water to which $\mathrm{NaOH}$ was added to a final concentration of $0.5 \mathrm{M}$.

For DMSPp analysis, samples of $15 \mathrm{ml}$ from the carboys or incubation bottles were gravity filtered onto a GF/F filter. DMSPp was analysed as DMS following alkaline hydrolysis of filters in $22 \mathrm{ml}$ sealed glass vials to which $0.5 \mathrm{M} \mathrm{NaOH}$ had been added. Subsamples of 1 to $5 \mathrm{ml}$ from the sealed vials were purged for 5 to

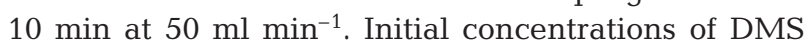
were determined in $10 \mathrm{ml}$ of filtrate, which was immediately transferred to a purge chamber for analysis. The filtrate was sparged with nitrogen at $50 \mathrm{ml} \mathrm{min}{ }^{-1}$ for $12.5 \mathrm{~min}$. The purged filtrate was used to determine DMSPd concentrations following hydrolysis with $\mathrm{NaOH}$ as for DMSPp samples. The purge gas was passed through a cold finger at $0^{\circ} \mathrm{C}$ followed by an ME Gas Dryer ${ }^{\mathrm{TM}}$ prior to entering a cryotrap consisting of a $1 / 16^{\prime \prime}(\sim 1.6 \mathrm{~mm})$ Teflon loop maintained at $-160^{\circ} \mathrm{C}$ above liquid nitrogen. After purging, the trap was heated to $95^{\circ} \mathrm{C}$ to transfer the trapped gas to the GC system. The detection limit of the system for DMS was approximately $50 \mathrm{pg} \mathrm{S}$. The precision (\% SE) of tripli- cate DMSPp and DMS measurements was typically 3.0 and $3.2 \%$, respectively.

Chl $\boldsymbol{a}$ analysis. The initial and final concentrations of $\mathrm{chl} a$ were determined by filtration of samples of 100 to $500 \mathrm{ml}$ onto $0.2 \mu \mathrm{m}$ polycarbonate filters and fluorometric analysis of chl a extracted in $90 \%$ acetone at $-20^{\circ} \mathrm{C}$. The precision ( $\% \mathrm{SE}$ ) of triplicate chl a measurements was typically $\leq 5.0 \%$.

Emiliania huxleyi abundance. The initial and final abundance of E. huxleyi was determined by analytical flow cytometry (AFC) of unfixed samples. AFC counts were performed with either a FACSort or FACScan flow cytometer (Becton Dickinson, Oxford, UK) equipped with $15 \mathrm{~mW}$ lasers exciting at $488 \mathrm{~nm}$ and with standard filter setups. Counts of quality control beads and nanophytoplankton on the 2 flow cytometers showed close agreement. Flow rates of the flow cytometers were calibrated routinely by measuring the changes in volume of samples run for differing lengths of time. Log measurements of side scatter (65 to $110^{\circ}$ ) and red $(>650 \mathrm{~nm})$ fluorescence were collected as listmode data, and plots were produced and analysed using the WinMDI freeware (Joseph Trotter, The Scripps Research Institute [http://facs.scripps.edu]). The lithed cells of E. huxleyi were distinguished from other nanophytoplankton by their high side scatter signals compared to other cells with similar levels of red (chl a) fluorescence. Counts of over 250 cells were required to obtain estimates of $E$. huxleyi abundance of high enough precision $(\leq 5 \% \mathrm{SE})$, requiring $>15 \mathrm{~min}$ sample runs for the most dilute incubations at a flow rate of approximately $100 \mu \mathrm{l} \mathrm{min}{ }^{-1}$.

Determination of primary production. At each of 8 depths within the euphotic zone $8 \times 60 \mathrm{ml}$ polycarbonate bottles were filled with sea water and inoculated with $10 \mathrm{mCi} \mathrm{NaH}^{14} \mathrm{CO}_{3}$. Two of each set of 8 bottles were incubated in the dark; the remainder were incubated in a series of on-deck incubators at 97 to $1 \%$ of ambient irradiance and at surface seawater temperature. Incubations were terminated after $24 \mathrm{~h}$ by filtration. The phytoplankton population was divided into $>5.0$ and 5.0 to $0.2 \mu \mathrm{m}$ by size fractionation onto appropriate polycarbonate filters. Filters were dried over silica gel prior to onboard counting of ${ }^{14} \mathrm{C}$ activity using a scintillation counter to determine total carbon uptake rates. Counts were corrected for counting efficiency using an external standard, channels ratio method.

Characterisation of the plankton. A combination of AFC of unfixed samples and microscopy of fixed samples was employed to characterise the phytoplankton communities in waters sampled for the dilution experiments. Phytoplankton larger than approximately $10 \mu \mathrm{m}$ were enumerated by inverted microscopy in $50 \mathrm{ml}$ subsamples fixed in acid Lugol's (1\% final concentration) and settled for $>72 \mathrm{~h}$. Linear dimensions of 
each taxon were used to calculate cell volume based on appropriate geometric shapes and converted to carbon according to Kovala \& Larrance (1966). Autotrophic cells smaller than approximately $10 \mu \mathrm{m}$ were enumerated using AFC (see above) and cell size determined by size fractionation (Tarran et al. 2001).

Microzooplankton taxonomy, abundance and biovolume were determined in samples from the undiluted carboy used in the set-up of dilution experiments. Samples of $250 \mathrm{ml}$ were fixed with acid Lugol's (1\% final concentration). Between 20 and $50 \mathrm{ml}$ subsamples were allowed to settle for $\geq 24 \mathrm{~h}$, and all heterotrophic individuals smaller than $200 \mu \mathrm{m}$ (excluding heterotrophic nanoflagellates $<20 \mu \mathrm{m}$ ) were identified and enumerated using an inverted microscope. The microzooplankton were sized using image analysis, and cell volumes were calculated assuming appropriate geometric shapes. The biovolume of each cell was then converted into carbon using conversion factors of $0.14 \mathrm{pg} \mathrm{C} \mathrm{mm}^{-3}$ for dinoflagellates (Lessard 1991) and 0.19 pg C $\mathrm{mm}^{-3}$ for ciliates (Putt \& Stoecker 1989). All ciliated protozoa were enumerated. Heterotrophic dinoflagellates were distinguished from autotrophic taxa according to Lessard \& Swift (1986).

Data analyses. Apparent rates of change $\left(k, \mathrm{~d}^{-1}\right)$ of DMSPp, chl $a$ and Emiliania huxleyi were calculated from mean $T_{0}$ values at each level of dilution and $T_{24}$ measurements from each incubation bottle, assuming an exponential model as described by Landry \& Hassett (1982). Model I regression analysis (Sokal \& Rohlf 1995) of the relationship between apparent rate of change and fraction of whole water was used to calculate estimates of instantaneous growth $\left(\mu, \mathrm{d}^{-1}\right)$ and loss due to grazing $\left(g, \mathrm{~d}^{-1}\right)$ for each of the 3 variables. The level of dilution (proportion of whole water in the dilution treatment) was calculated from initial concentrations of each variable relative to the concentration in unfiltered water.

\section{RESULTS}

\section{Community composition, primary production and DMSPp}

The initial concentrations of chl $a$, DMSPp and specific phytoplankton taxa in the waters used for dilution experiments are listed in Table 2. Chl a concentrations were relatively low and DMSPp concentrations high,

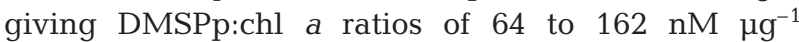
(Table 2). Despite being the most obvious component of the phytoplankton community in surface water, Emiliania huxleyi abundance was moderate, ranging from 536 to $1092 \times 10^{3}$ cells $1^{-1}$ (Table 2 ). Another notable component was the autotrophic dinoflagellate Prorocentrum minimum, which occurred at concentrations of 0 to $221 \times 10^{3}$ cells $1^{-1}$ (Table 2). Other autotrophic nanophytoplankton (510 to $2660 \times 10^{3}$ cells $\mathrm{l}^{-1}$ ) and au-

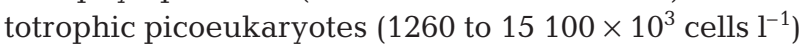
were also a conspicuous component of the phytoplankton communities. In contrast, diatoms were relatively scarce and contributed only a minor proportion $(\leq 7 \%)$ of the phytoplankton biomass in surface waters.

Based on a value of $1.3 \mathrm{pg}$ DMSP cell-1 ${ }^{-1}$ (Keller et al. 1989, S.D.A. unpubl.), Emiliania huxleyi contributed 5 to $15 \%$ of the total DMSPp (Fig. 1). The population of Prorocentrum minimum was most abundant during the Lagrangian phase of the study but absent in the latter 2 experiments; it contributed an estimated 0 to $35 \%$ of the total DMSPp (Fig. 1), based on a cell-specific content of 21.4 pg DMSP cell ${ }^{-1}$ (Keller et al. 1989). Rough approximations of the DMSPp content of the other autotrophic dinoflagellates, nanophytoplankton and the autotrophic picoeukaryotes suggest that the source of almost $50 \%$ of the total DMSPp is undefined on some dates (Fig. 1).

Primary production determined as the rate of incorporation of ${ }^{14} \mathrm{C}$ in both $>5 \mu \mathrm{m}$ and 5 to $0.2 \mu \mathrm{m}$ size frac-

Table 2. Biological and chemical characteristics of the water used in the dilution experiments. Shown are the initial concentrations of chlorophyll a $(\mathrm{chl}$ a), DMSPp, DMSPd, DMS, the abundance of the DMSP-rich phytoplankton Emiliania huxleyi and Prorocentrum minimum, microzooplankton (MZP) biomass and the abundance of the dominant ciliate taxon, provisionally identified as Strombidium ovale. Also included are estimates of primary production $\left({ }^{14} \mathrm{C} \mathrm{PP}\right)$ measured in water sampled at the same depths and times as water used for the dilution experiments

\begin{tabular}{|c|c|c|c|c|c|c|c|c|c|c|}
\hline $\begin{array}{l}\text { Day in } \\
\text { June }\end{array}$ & $\begin{array}{c}\mathrm{Chl} \mathrm{a} \\
\left(\mu \mathrm{g} \mathrm{l}^{-1}\right)\end{array}$ & $\begin{array}{c}{ }^{14} \mathrm{C} \mathrm{PP}^{-1} \\
\left(\mathrm{nM} \mathrm{C} \mathrm{d}^{-1}\right)\end{array}$ & $\begin{array}{l}\text { DMSPp } \\
\text { (nM) }\end{array}$ & $\begin{array}{l}\text { DMS } \\
\text { (nM) }\end{array}$ & $\begin{array}{c}\text { DMSPd } \\
(\mathrm{nM})\end{array}$ & $\begin{array}{l}\text { DMSP:chl } a \\
\left({\left.\mathrm{nM} \mu \mathrm{g}^{-1}\right)}^{-1}\right.\end{array}$ & $\begin{array}{c}\text { E. huxleyi } \\
\left(10^{3} \text { cells } 1^{-1}\right)\end{array}$ & $\begin{array}{l}\text { P. minimum } \\
\left(10^{3} \text { cells } 1^{-1}\right)\end{array}$ & $\begin{array}{c}\text { MZP } \\
\left(\mu \mathrm{C}^{-1}\right)\end{array}$ & $\begin{array}{l}\text { S. ovale-type } \\
\left(10^{3} \text { cells } 1^{-1}\right)\end{array}$ \\
\hline 18 & 0.40 & 1480 & 64 & 3.7 & 4.9 & $153( \pm 9)$ & 536 & 108 & 25.5 & 6.4 \\
\hline 19 & 0.43 & 1990 & 54 & 3.9 & 4.4 & $131( \pm 6)$ & 657 & 118 & 28.1 & 4.0 \\
\hline 21 & 0.91 & 2770 & 59 & 4.0 & 16.4 & $64( \pm 3)$ & 895 & 125 & 41.0 & 8.7 \\
\hline 22 & 1.03 & 2510 & 68 & 4.6 & 9.3 & $70( \pm 7)$ & 1092 & 81 & 37.6 & 7.6 \\
\hline 24 & 0.74 & 1690 & 121 & 5.2 & 8.4 & $162( \pm 13)$ & 641 & 221 & 31.1 & 2.5 \\
\hline 26 & 0.60 & 2040 & 76 & 7.9 & 8.1 & $121( \pm 7)$ & 607 & 48 & 32.3 & 4.0 \\
\hline 27 & 0.73 & 1880 & 74 & 4.6 & 8.3 & $105( \pm 8)$ & 550 & 0 & 48.8 & 2.7 \\
\hline 28 & 0.62 & 2040 & 82 & 10.1 & 11.6 & $138( \pm 9)$ & 570 & 0 & 56.7 & 5.8 \\
\hline
\end{tabular}




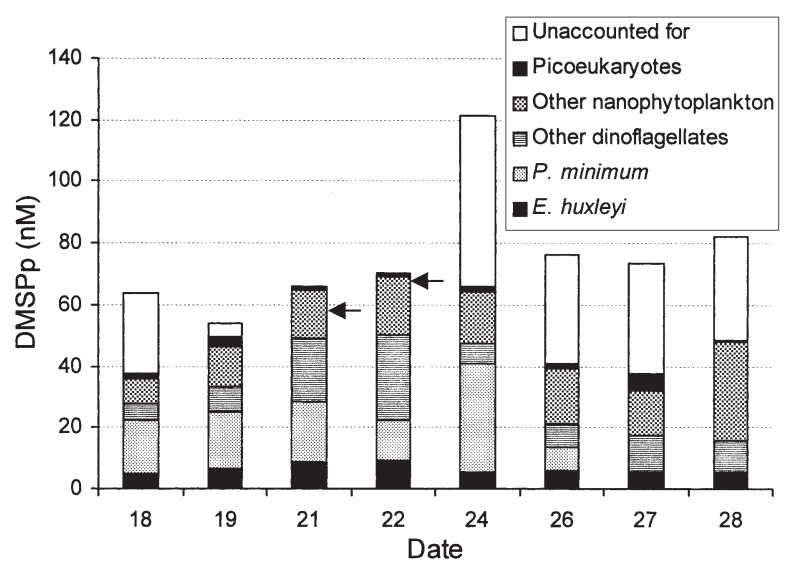

Fig. 1. Contribution of phytoplankton taxonomic groups to the DMSPp pool in waters used for the dilution experiments based on taxon-specific cell abundance and DMSPp cell content. DMSP cell contents used in the analysis were: Emiliania huxleyi, $1.3 \mathrm{pg} \mathrm{cell}^{-1}$ (Keller et al. 1989, S.D.A. unpubl.); Prorocentrum minimum, $21.4 \mathrm{pg} \mathrm{cell}^{-1}$ (Keller et al. 1989); other dinoflagellates were allocated the same biomass-specific DMSP content to $P$. minimum (0.47 pg DMSP pg $\left.{ }^{-1} \mathrm{C}\right)$ and consist of cells enumerated and sized by microscopy that were larger than $10 \mu \mathrm{m}$ in diameter; other nanophytoplankton were allocated a biomass-specific DMSP content (0.19 pg DMSP $\mathrm{pg}^{-1} \mathrm{C}$ ), half that of E. huxleyi and consisted of cells of 2 to $10 \mu \mathrm{m}$ diameter enumerated by flow cytometry; eukaryotic picophytoplankton $0.0465 \mathrm{pg} \mathrm{cell}^{-1}$ (Corn et al. 1996). The amount of measured DMSPp not accounted for by these phytoplankton groups is also shown. On 2 occasions the combined estimates of phytoplankton DMSP exceed the mea sured values of total DMSPp as indicated by arrows

tions ranged from 17.8 to $33.2 \mu \mathrm{C}^{-1} \mathrm{~d}^{-1}$, equivalent to 1480 to $2770 \mathrm{nM} \mathrm{C} \mathrm{d}^{-1}$ at the depths of water sampled for the dilution experiments (Table 1). These values are total rates of ${ }^{14} \mathrm{C}$ incorporation and as such include the synthesis of inorganic coccolithophore liths.

In the waters used for dilution experiments, microzooplankton biomass ranged from 25.5 to $56.7 \mu \mathrm{g} \mathrm{Cl}^{-1}$ (Table 2). During the Lagrangian phase of the study, biomass was dominated by oligotrich ciliates; in particular a ciliate resembling Strombidium ovale (mean diameter $46 \mu \mathrm{m}$ ) that occurred at an abundance of between 2500 and 8700 cells $1^{-1}$ (Table 2). Although similar concentrations of $S$. ovale occurred in the latter 3 experiments, heterotrophic dinoflagellates made up an increasingly higher proportion (38 to $59 \%$ ) of the total microzooplankton biomass. Athecate heterotrophic dinoflagellates contributed the major proportion of biomass in samples from the Lagrangian phase and comprised both Gymnodinium spp. and Gyrodinium spp. The higher heterotrophic dinoflagellate biomass recorded on the other 3 dates was largely the result of increased thecate dinoflagellate abundance. In partic- ular, on 27 and 28 June a large (90 $\mu$ m diameter) Protoperidinium sp. made up almost half of the heterotrophic dinoflagellate biomass.

\section{DMSPp dynamics in dilution experiments}

Apparent DMSPp production occurred in all incubations except on 24 June, when an apparent loss of DMSPp occurred in less dilute incubations (Fig. 2). In addition, increasing apparent growth of DMSPp occurred in response to increasing levels of dilution and therefore decreasing grazing pressure. The model I linear regression relationship between apparent growth of DMSPp and fraction of whole water was significant $(\mathrm{p}<0.05)$ in all 8 experiments (Fig. 2, Table 3A).

Instantaneous growth rates of DMSPp in the absence of grazing $\left(\mu_{\mathrm{dmsp}}\right)$ were calculated from the $y$-intercept of the regression. Estimates of $\mu_{\mathrm{dmsp}}$ were similar between experiments, ranging from 0.26 to $0.58 \mathrm{~d}^{-1}$ (Table 3A). No DMSPp measurements were made in control incubations. However, based on the ratio of apparent chl a growth in undiluted waters to which nutrients were added $\left(k_{\mathrm{n}}\right)$ and control incubations to which no nutrients were added $\left(k_{\mathrm{c}}\right)$, estimates of the 'in situ' instantaneous growth rates of DMSPp ranged from 0.23 to $0.58 \mathrm{~d}^{-1}$ (Table 3A). This is equivalent to a total DMSPp doubling time of 1.2 to $3.0 \mathrm{~d}$. 'In situ' DMSPp potential production increased over the first $4 \mathrm{~d}$ of the Lagrangian study from 14.8 to $45.6 \mathrm{nM} \mathrm{d}^{-1}$ and dropped to $25.5 \mathrm{nM} \mathrm{d}^{-1}$ on 24 June (Table 3A). On the 3 dates following the Lagrangian study DMSPp production averaged $25.0 \mathrm{nM} \mathrm{d}^{-1}$ (Table 3A).

The slope of the regression between apparent growth and fraction of whole water provides an estimate of the rate of DMSPp loss due to grazing ( $\left.g_{\mathrm{dmsp}}\right)$. Estimates of $g_{\text {dmsp }}$ varied from 0.18 to $0.56 \mathrm{~d}^{-1}$ in the experiments (Table 3A). Values of $g_{\text {dmsp }}$ suggest a turnover rate of DMSPp by microzooplankton grazers of 16 to $43 \% \mathrm{~d}^{-1}$ (turnover time of 6.2 to $2.3 \mathrm{~d}$ ) during the Lagrangian study and an average of $29 \% \mathrm{~d}^{-1}$ (turnover time of $3.5 \mathrm{~d}$ ) on the following 3 dates (Table 3A). This is equivalent to DMSPp losses of 11.4 to $59.9 \mathrm{nM} \mathrm{d}^{-1}$ during the Lagrangian study and an average of $27.9 \mathrm{nM} \mathrm{d}^{-1}$ at the other 3 stations. Potential production rates of DMSPp based on the 'in situ' values generally exceeded rates of loss due to grazing during the Lagrangian study (Table 3A). The amount of DMSPp consumed by microzooplankton averaged $62 \% \mathrm{~d}^{-1}$ of potential production during the first $4 \mathrm{~d}$ of the Lagrangian phase but increased dramatically on 24 June to almost $200 \% \mathrm{~d}^{-1}$. On the 27 and 28 June, all potential DMSPp production was consumed by grazers (Table 3A). 


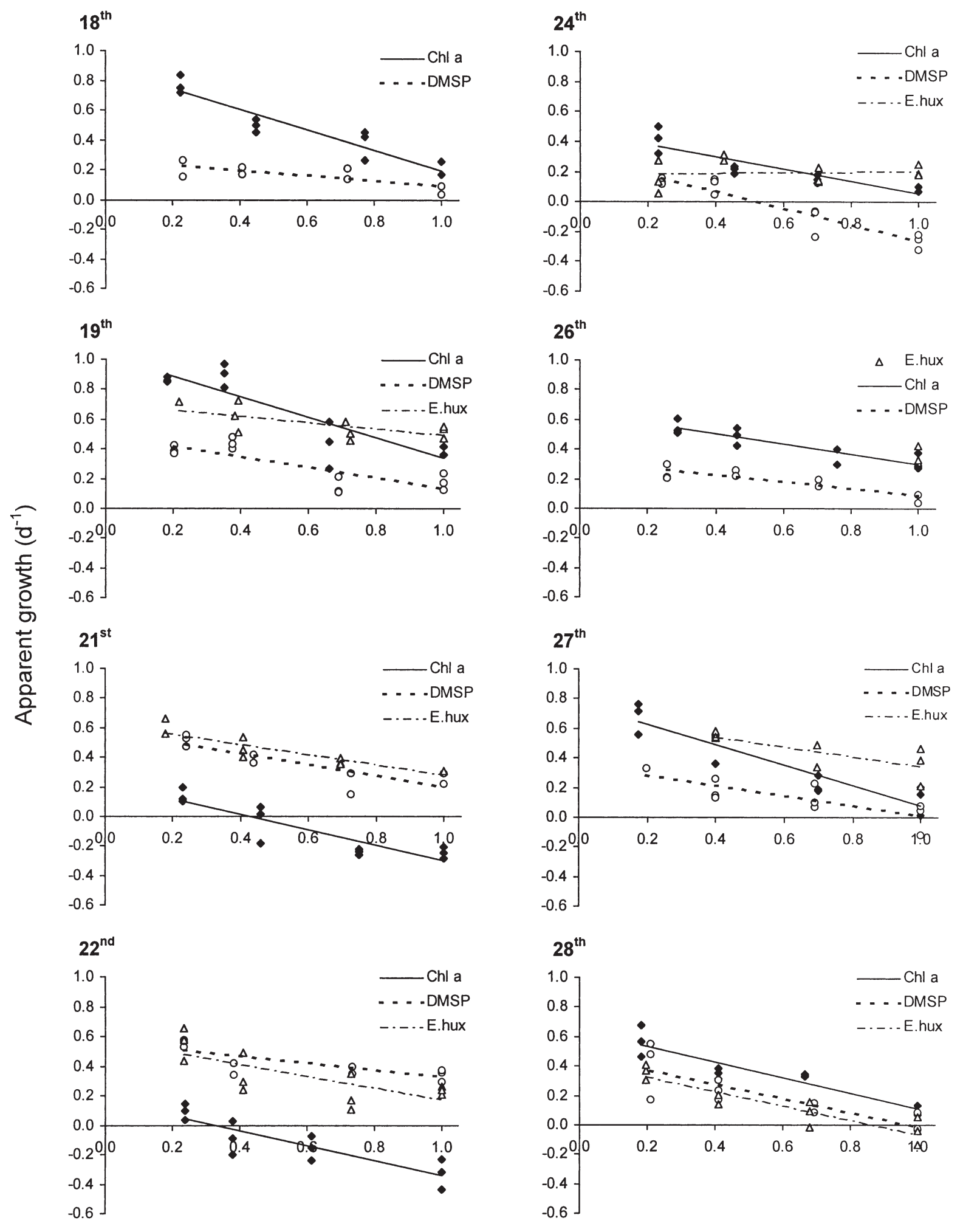

Fraction of whole water

Fig. 2. Relationship between apparent change in DMSPp, chl a and Emiliania huxleyi and the level of dilution (fraction of whole water) in the 8 dilution experiments in June. The values of the regression analyses are given in Table 3 
Table 3. Instantaneous growth rate $(\mu)$ and loss due to grazing $(g)$ calculated from the regression between apparent growth and dilution factor (Fig. 2) for (A) DMSPp (nM), (B) chl a ( $\mu \mathrm{g} \mathrm{l}^{-1}$ ) and (C) Emiliania huxleyi $\left(\times 10^{3} \mathrm{cells}^{-1}\right)$. Values of $\mu_{\mathrm{n}}$ and $\mu_{\mathrm{c}}$ are rates in incubations with nutrient addition and corrected to 'in situ' rates based on control incubations with no nutrient addition, respectively. $\mathrm{p}$ is the significance of the $F$-ratio of the analysis of variance of the model 1 regression of each dilution experiment. The mean concentration $\left(\hat{\mathrm{c}}=\left[C_{t}-C_{0}\right] /\left[\ln C_{t}-\ln C_{0}\right]\right)$, potential production $\left(P_{\mathrm{p}}=\mu_{\mathrm{c}} \cdot \hat{\mathrm{c}}\right)$, production consumed $\left(P_{\mathrm{c}}=g \cdot \hat{\mathrm{c}}\right)$ and \% of production grazed $\left[P_{\mathrm{g}}=\left(\mu_{\mathrm{c}} / g\right) \cdot 100\right]$ and turnover rates $\left(=1-\mathrm{e}^{-g} \cdot 100\right)$ are shown. $\mu_{\mathrm{n} \text { dmsp }}$ were adjusted to $\mu_{\mathrm{c} \text { dmsp }}$ according to the ratio $\mu_{\mathrm{c}}: \mu_{\mathrm{n}}$ calculated from chl $a$ analyses (see [B]). ${ }^{*}$ No significant difference $(t$-test, $\mathrm{p}<0.05$ ) between triplicate controls and nutrient addition incubations; ${ }^{* *}$ no control incubations analysed; ${ }^{* * *}$ net growth rate in undiluted water. ns: not significant; nd: no data

\begin{tabular}{|c|c|c|c|c|c|c|c|c|c|}
\hline $\begin{array}{l}\text { Day in } \\
\text { June }\end{array}$ & $\begin{array}{c}\mu_{\mathrm{n}} \\
\left(\mathrm{d}^{-1}\right)\end{array}$ & $\begin{array}{c}\mu_{\mathrm{c}} \\
\left(\mathrm{d}^{-1}\right)\end{array}$ & $\begin{array}{c}g \\
\left(\mathrm{~d}^{-1}\right)\end{array}$ & $\mathrm{p}$ & $\hat{\mathrm{C}}$ & $\begin{array}{c}P_{\mathrm{p}} \\
\left(\mathrm{d}^{-1}\right)\end{array}$ & $\begin{array}{c}P_{\mathrm{c}} \\
\left(\mathrm{d}^{-1}\right)\end{array}$ & $\begin{array}{c}P_{\mathrm{g}} \\
\left(\% \mathrm{~d}^{-1}\right)\end{array}$ & $\begin{array}{c}\text { Turnover } \\
\left(\% d^{-1}\right)\end{array}$ \\
\hline \multicolumn{10}{|c|}{ (A) DMSPp } \\
\hline 18 & $0.26( \pm 0.04)$ & 0.23 & $0.18( \pm 0.06)$ & 0.023 & 65 & 14.8 & 11.4 & 67 & 16 \\
\hline 19 & $0.49( \pm 0.05)$ & 0.41 & $0.35( \pm 0.08)$ & 0.001 & 59 & 24.5 & 20.9 & 72 & 30 \\
\hline 21 & $0.58( \pm 0.06)$ & $0.58^{*}$ & $0.38( \pm 0.09)$ & 0.003 & 67 & 38.9 & 25.6 & 66 & 32 \\
\hline 22 & $0.56( \pm 0.04)$ & $0.56^{*}$ & $0.24( \pm 0.07)$ & 0.007 & 81 & 45.6 & 19.1 & 42 & 21 \\
\hline 24 & $0.29( \pm 0.04)$ & 0.24 & $0.56( \pm 0.06)$ & 0.000 & 107 & 25.5 & 59.9 & 192 & 43 \\
\hline 26 & $0.32( \pm 0.03)$ & $0.32^{*}$ & $0.23( \pm 0.05)$ & 0.001 & 79 & 25.0 & 18.4 & 74 & 21 \\
\hline 27 & $0.35( \pm 0.07)$ & 0.25 & $0.34( \pm 0.09)$ & 0.007 & 74 & 18.3 & 25.2 & 98 & 29 \\
\hline 28 & $0.47( \pm 0.07)$ & 0.38 & $0.48( \pm 0.10)$ & 0.001 & 83 & 31.6 & 40.1 & 103 & 38 \\
\hline \multicolumn{10}{|c|}{ (B) Chlorophyll a } \\
\hline 18 & $0.87( \pm 0.06)$ & 0.75 & $0.67( \pm 0.09)$ & 0.000 & 0.44 & 0.332 & 0.299 & 90 & 49 \\
\hline 19 & $1.03( \pm 0.08)$ & 0.87 & $0.69( \pm 0.14)$ & 0.000 & 0.49 & 0.428 & 0.335 & 78 & 49 \\
\hline 21 & $0.23( \pm 0.06)$ & $0.23^{*}$ & $0.53( \pm 0.10)$ & 0.000 & 0.81 & 0.180 & 0.424 & 235 & 41 \\
\hline 22 & $0.19( \pm 0.06)$ & $0.19^{*}$ & $0.57( \pm 0.10)$ & 0.000 & 0.88 & 0.142 & 0.441 & 311 & 40 \\
\hline 24 & $0.46( \pm 0.05)$ & 0.34 & $0.40( \pm 0.07)$ & 0.000 & 0.73 & 0.378 & 0.289 & 77 & 33 \\
\hline 26 & $0.66( \pm 0.04)$ & $0.66^{*}$ & $0.38( \pm 0.05)$ & 0.000 & 0.70 & 0.451 & 0.239 & 53 & 29 \\
\hline 27 & $0.79( \pm 0.06)$ & 0.56 & $0.75( \pm 0.09)$ & 0.000 & 0.69 & 0.385 & 0.475 & 123 & 50 \\
\hline 28 & $0.64( \pm 0.05)$ & 0.52 & $0.54( \pm 0.08)$ & 0.000 & 0.62 & 0.322 & 0.326 & 101 & 41 \\
\hline \multicolumn{10}{|c|}{ (C) Emiliania huxleyi } \\
\hline 18 & nd & nd & nd & nd & nd & nd & nd & nd & nd \\
\hline 19 & $0.72( \pm 0.06)$ & $0.72^{* *}$ & $0.24( \pm 0.01)$ & 0.039 & 872 & 629 & 212 & 34 & 22 \\
\hline 21 & $0.64( \pm 0.04)$ & 0.54 & $0.37( \pm 0.07)$ & 0.001 & 998 & 537 & 373 & 69 & 31 \\
\hline 22 & $0.58( \pm 0.09)$ & $0.58^{*}$ & $0.42( \pm 0.14)$ & 0.015 & 1099 & 637 & 459 & 72 & 34 \\
\hline 24 & $0.19( \pm 0.06)$ & $0.19^{*}$ & ns & 0.810 & nd & nd & nd & nd & nd \\
\hline 26 & $0.36( \pm 0.06)$ & $0.36^{* * *}$ & nd & 0.044 & 735 & nd & nd & nd & nd \\
\hline 27 & $0.69( \pm 0.10)$ & $0.69^{*}$ & $0.36( \pm 0.14)$ & 0.054 & 667 & 459 & 241 & 53 & 30 \\
\hline 28 & $0.43( \pm 0.05)$ & 0.12 & $0.50( \pm 0.09)$ & 0.000 & 479 & 59 & 238 & 401 & 39 \\
\hline
\end{tabular}

\section{Chl a dynamics in dilution experiments}

The model I linear regression relationship between apparent growth of chl $a$ and fraction of whole water was highly significant $(\mathrm{p}<0.001)$ in all 8 experiments (Fig. 2, Table 3B). Significant differences ( $t$-test, $\mathrm{p}<$ $0.05)$ between apparent growth rate in undiluted incubations with $\left(k_{\mathrm{n}}\right)$ and without $\left(k_{\mathrm{c}}\right)$ added nutrients occurred in 5 of the 8 experiments. The ratio between measured $\left(\mu_{\mathrm{n}}\right)$ and adjusted instantaneous growth rate $\left(\mu_{\mathrm{c}}\right)$ varied from 0.71 to 1.00 in the 5 experiments. Adjusted 'in situ' $\mu_{\mathrm{chl}}$ ranged from 0.19 to $0.87 \mathrm{~d}^{-1}$ during the Lagrangian study and from 0.52 to $0.66 \mathrm{~d}^{-1}$ on the following $3 \mathrm{~d}$. These values represent a potential

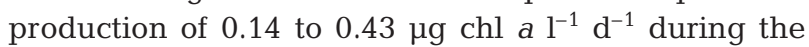

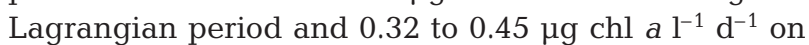
subsequent dates (Table 3B). Values of the coefficient of mortality rate due to microzooplankton grazing $\left(g_{\mathrm{chl}}\right)$ decreased during the Lagrangian period, with resulting turnover rates of 49 to $33 \% \mathrm{~d}^{-1}$ (turnover times of 2.0 to $3.0 \mathrm{~d}$ ) (Table 3B). However, the quantity of production that was consumed remained similar, ranging from 0.29 to $0.44 \mu \mathrm{g}$ chl a $\mathrm{l}^{-1} \mathrm{~d}^{-1}$ on the dates of the

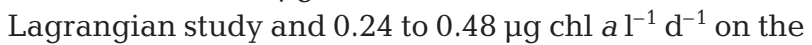
following days (Table 3B). Low rates of potential production on 21 and 22 June largely explain the imbalance between the potential production and production consumed on those dates. On the remaining dates potential production matched or exceeded the rates of consumption by microzooplankton (Table 3B).

\section{Emiliania huxleyi dynamics in dilution experiments}

The model I regression between apparent growth of Emiliania huxleyi and fraction of whole water was sig- 
nificant $(p<0.05)$ on 5 of the 6 days on which cell counts were conducted. Apparent growth of E. huxleyi in undiluted incubations did not react to nutrient addition in the same way as chl $a$. In only 2 of the 5 experiments in which $k_{\mathrm{c}}$ for $E$. huxleyi was determined did significant differences occur between $k_{\mathrm{c}}$ and $k_{\mathrm{n}}$. Values of $k_{\mathrm{c}}$ were not determined on 19 June, and therefore $\mu_{\text {Ehux }}$ may be overestimated on that date. In addition, incomplete counts of the most dilute incubations on 27 June resulted in estimates of net growth for only 3 levels of dilution. On the 3 dates during the Lagrangian study on which significant regression results were obtained, instantaneous growth rates were close to 1 doubling $\mathrm{d}^{-1}$ and represented similar potential production rates of 537 to $637 \times 10^{3}$ cells l$^{-1}$ $\mathrm{d}^{-1}$ (Table 3C). A similar rate of growth and potential production occurred on 27 June. On 28 June, a ratio for $\mu_{\mathrm{c}}: \mu_{\mathrm{n}}$ of 0.24 reduced the instantaneous rate of growth to $0.12 \mathrm{~d}^{-1}$, equivalent to a potential production of only $59 \times 10^{3}$ cells $\mathrm{l}^{-1} \mathrm{~d}^{-1}$ (Table 3 C). In general, rates of mortality due to microzooplankton grazing were lower than potential production and represented a similar rate of turnover of 22 to $39 \% \mathrm{~d}^{-1}$ of the initial standing stock (turnover time of 2.6 to $4.6 \mathrm{~d}$ ) in all 5 experiments (Table 3C).

\section{Comparison of growth rates}

Apparent rates of DMSPp growth were not measured in control incubations, and values of $\mu_{\mathrm{dmsp}}$ were adjusted to 'in situ' rates based on the differences in net production of chl $a$ in control and nutrient amended incubations. However, it is possible that the DMSPp producing phytoplankton reacted differently to nutrient addition than the bulk community represented by chl a. Instantaneous growth rates not adjusted for potential nutrient limitation averaged 0.41 $( \pm 0.12) \mathrm{d}^{-1}$ for DMSPp, $0.54( \pm 0.18) \mathrm{d}^{-1}$ for Emiliania huxleyi and $0.60( \pm 0.30) \mathrm{d}^{-1}$ for chl $a$. The mean rates once values were adjusted to 'in situ' nutrient levels were $0.37( \pm 0.14), 0.47( \pm 0.26)$ and $0.53( \pm 0.24) \mathrm{d}^{-1}$, respectively. The adjusted values represent a mean doubling time of 1.9, 1.5 and $1.3 \mathrm{~d}$, respectively. When either nutrient addition or 'in situ' values of $\mu$ are compared (Fig. 3A), $\mu_{\text {dmsp }}$ was lower than $\mu_{\text {chl, }}$ except on 21 and 22 June, when $\mu_{\mathrm{dmsp}}$ exceeded the rates for chl $a$ largely due to lower growth rates of chl a (Table 3). When 'in situ' values of $\mu$ are compared, $\mu_{\text {Ehux }}$ was also higher than $\mu_{\mathrm{chl}}$ on the 21 and 22 June, but similar to or lower on 19, 27, 28 June (Table 3, Fig. 3A). If 'in situ' values are compared, $\mu_{\mathrm{dmsp}}$ was lower than or similar to $\mu_{\text {Ehux }}$ except on 28 June, when low rates of net growth of $E$. huxleyi in control incubations reduced $\mu_{\text {Ehux }}$ from 0.47 to $0.12 \mathrm{~d}^{-1}$ (Fig. 3A).

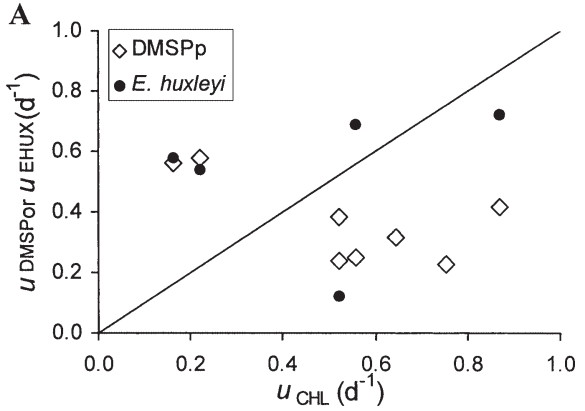

B

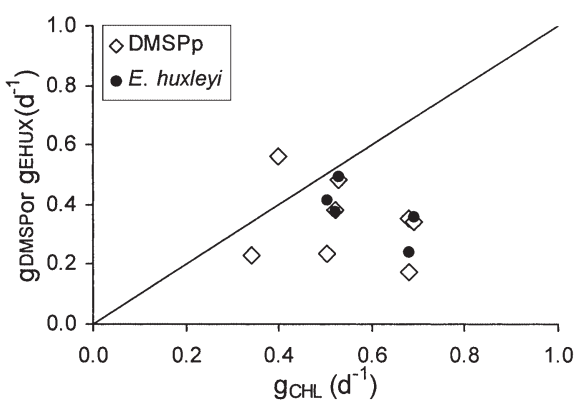

C

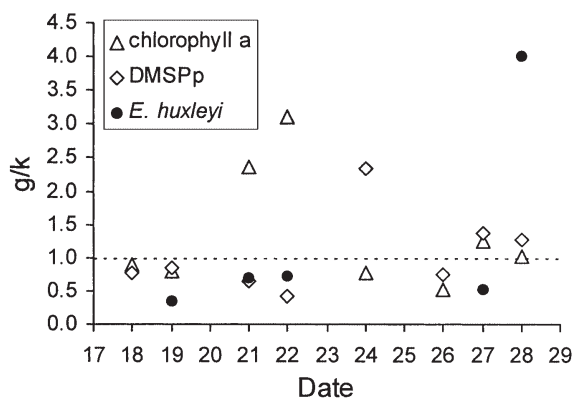

Fig. 3. Growth (A) and grazing (B) coefficients of DMSPp and Emiliania huxleyi compared to chl $a$ and $(\mathrm{C})$ the proportion of production grazed $(g / k)$ for chl $a$, DMSPp and E. huxleyi on each experimental date. The lines in (A) and (B) represent identical growth and grazing rates to $\mathrm{chl} a$, and in (C) the dotted line represents growth rates balanced by grazing rates

\section{Comparison of mortality rates due to grazing}

The slope of the regression $(g)$ for the level of dilution versus DMSPp and Emiliania huxleyi was generally lower than that of chl a (Fig. 3B). In 4 of the 8 experiments, $g_{\text {dmsp }}$ was significantly lower $(p<0.05)$ than $g_{\text {chl }}$ and was not significantly different from $g_{\text {Ehux }}$ on 4 of 5 comparisons (Table 4). Mean values of $g$ during the study were $0.35( \pm 0.13) \mathrm{d}^{-1}$ for DMSPp, $0.36( \pm 0.10) \mathrm{d}^{-1}$ for E. huxleyi and $0.54( \pm 0.13) \mathrm{d}^{-1}$ for $\mathrm{chl} a$. This is equivalent to mean turnover rates of $30.6( \pm 9.0), 29.7( \pm 6.9)$ and $40.3( \pm 7.8) \% \mathrm{~d}^{-1}$, respectively. 
Table 4. Comparison of coefficients of mortality $(g)$ for chlorophyll a (chl a), DMSPp and Emiliania huxleyi. Values are the level of significance of an $F$-test for the difference between pairs of regression coefficients (Sokal \& Rohlf 1995): similar $=$ no significant difference at $\mathrm{p}<0.05 ; \mathrm{nd}=$ no data

\begin{tabular}{|c|c|c|c|}
\hline Day in June & & DMSPp & E. huxleyi \\
\hline 18 & $\begin{array}{l}\text { Chl a } \\
\text { E. huxleyi }\end{array}$ & $\begin{array}{c}\mathrm{p}<0.001 \\
\text { nd }\end{array}$ & nd \\
\hline 19 & $\begin{array}{l}\text { Chl a } \\
\text { E. huxleyi }\end{array}$ & $\begin{array}{l}\mathrm{p}<0.05 \\
\text { Similar }\end{array}$ & $\mathrm{p}<0.025$ \\
\hline 21 & $\begin{array}{l}\text { Chl a } \\
\text { E. huxleyi }\end{array}$ & $\begin{array}{l}\text { Similar } \\
\text { Similar }\end{array}$ & Similar \\
\hline 22 & $\begin{array}{l}\text { Chl a } \\
\text { E. huxleyi }\end{array}$ & $\begin{array}{l}\mathrm{p}<0.01 \\
\text { Similar }\end{array}$ & Similar \\
\hline 24 & $\begin{array}{l}\text { Chl a } \\
\text { E. huxleyi }\end{array}$ & $\begin{array}{c}\text { Similar } \\
\mathrm{p}<0.001\end{array}$ & $\mathrm{p}<0.001$ \\
\hline 26 & $\begin{array}{l}\text { Chl a } \\
\text { E. huxleyi }\end{array}$ & $\begin{array}{c}\text { Similar } \\
\text { nd }\end{array}$ & nd \\
\hline 27 & $\begin{array}{l}\text { Chl a } \\
\text { E. huxleyi }\end{array}$ & $\begin{array}{c}\mathrm{p}<0.01 \\
\text { nd }\end{array}$ & $\mathrm{p}<0.025$ \\
\hline 28 & $\begin{array}{l}\text { Chl a } \\
\text { E. huxleyi }\end{array}$ & $\begin{array}{l}\text { Similar } \\
\text { Similar }\end{array}$ & Similar \\
\hline
\end{tabular}

\section{DISCUSSION}

In surface waters of the northern North Sea containing DMSP-rich phytoplankton, DMSPp production rates estimated by the dilution approach ranged from 14.8 to $45.6 \mathrm{nM} \mathrm{d}^{-1}$ and represent a doubling time of the ambient DMSPp pool of between 1.2 and $3.1 \mathrm{~d}$ (Table 3A). Consumption rates of DMSPp by microzooplankton varied between 11.4 and $59.9 \mathrm{nM} \mathrm{d}^{-1}$ and were equivalent to turnover rates of the ambient DMSPp pool of between 16 and $43 \% \mathrm{~d}^{-1}$ (Table 3A). The high significance of the regression analyses (generally $\mathrm{p}<0.01$; Fig. 2, Table 3A) on which these production and consumption values are based indicates that they are robust and meaningful.
One way to gauge how tenable the values are is to compare them to 3 other studies that have measured DMSPp production/consumption rates (Table 5). Wolfe et al. (2000) measured net changes in DMSPp using a similar dilution approach to the present study. In 2 experiments conducted on the Newfoundland and Labrador shelf, the regression analyses of the dilution plots appear to be significant ( $\mathrm{p} \leq 0.05, \mathrm{n}=8, \mathrm{r}^{2}=0.50$ ) and instantaneous growth rates of the phytoplankton community based on chl a were positive. Values of $\mu_{\text {dmsp }}$ were 0.47 and $0.18 \mathrm{~d}^{-1}$ and for $g_{\text {dmsp }}$ were 0.10 and $0.22 \mathrm{~d}^{-1}$ from these 2 experiments. Using these data, production and consumption rates of DMSPp can be calculated (Table 5) that are equivalent to DMSPp doubling times of 1.5 and $3.9 \mathrm{~d}$ and a turnover rate of 10 and $20 \% \mathrm{~d}^{-1}$, respectively. Water temperatures were lower $\left(-0.1\right.$ and $\left.-0.4^{\circ} \mathrm{C}\right)$ and chl a concentrations

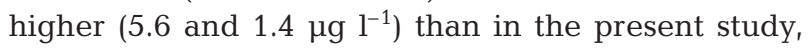
and differences in the phytoplankton community structure may account for the microzooplankton consumption rates being lower than those found in the present study. Nevertheless, the results are comparable to those measured in the northern North Sea in summer.

During early spring off the Washington Coast, estimates of DMSPp production based on the incorporation rate of ${ }^{35} \mathrm{SO}_{4}{ }^{2-}$ (Table 5) are likely to have been underestimates due to probable losses during sample filtration and freezing (Bates et al. 1994). Despite this, the deeply mixed $(60 \mathrm{~m})$ water column and a phytoplankton community dominated by picoplankton, particularly Synechococcus spp., the DMSPp production rates still represent $10 \% \mathrm{~d}^{-1}$ of the DMSPp standing stock. DMSPp production rates in the present study averaged $40 \% \mathrm{~d}^{-1}$ of the standing stock.

Similar rates of DMSPp production to the present study were obtained by budgeting concentrations and transformation rates of total DMSP (dissolved + particulate) between Lagrangian samplings (Table 5) (Simó \& Pedrós-Alió 1999). These estimates were carried out

Table 5. Comparable estimates of rates of DMSPp production and turnover

\begin{tabular}{|c|c|c|c|c|c|c|c|}
\hline Method & Location & $\begin{array}{l}\text { Depth } \\
(\mathrm{m})\end{array}$ & $\begin{array}{c}\text { Chl } a \\
\left(\mu \mathrm{g} \mathrm{l}^{-1}\right)\end{array}$ & $\begin{array}{l}\text { DMSP } \\
(\mathrm{nM})\end{array}$ & $\begin{array}{l}\text { DMSPp production } \\
\qquad\left(\mathrm{nM} \mathrm{d}^{-1}\right)\end{array}$ & $\begin{array}{l}\text { DMSPp turnover } \\
\quad\left(\mathrm{nM} \mathrm{d}^{-1}\right)\end{array}$ & Source \\
\hline $\begin{array}{l}\text { Dilution } \\
\text { approach }\end{array}$ & $\begin{array}{l}\text { Newfoundland and } \\
\text { Labrador shelf }\end{array}$ & $\begin{array}{c}3 \\
20\end{array}$ & $\begin{array}{l}5.6 \\
1.4\end{array}$ & $\begin{array}{c}46 \\
112\end{array}$ & $\begin{array}{l}26 \\
21\end{array}$ & $\begin{array}{c}6 \\
26\end{array}$ & $\begin{array}{l}\text { Wolfe et al. } \\
\text { (2000) }\end{array}$ \\
\hline $\begin{array}{l}{ }^{35} \mathrm{SO}_{4}{ }^{2-} \\
\text { uptake }\end{array}$ & $\begin{array}{l}\text { NE Pacific } \\
\text { waters }\end{array}$ & $\begin{array}{l}\text { Average for } \\
\text { top } 60 \mathrm{~m}\end{array}$ & $<0.4$ & 16.7 & 1.8 & $\begin{array}{c}3.8 \text { (based on } \\
\text { carbon turnover) }\end{array}$ & $\begin{array}{l}\text { Bates et al. } \\
\quad(1994)\end{array}$ \\
\hline $\begin{array}{l}\text { Incubations plus } \\
\text { Lagrangian expt }\end{array}$ & $\begin{array}{ll}s & \text { Iceland Basin } \\
t & \end{array}$ & Surface & $0.85-0.50$ & $30-50$ & $11.3-30.9$ & $\begin{array}{c}\begin{array}{c}8.1-50.6 \\
\text { (total DMSP) }\end{array}\end{array}$ & $\begin{array}{l}\text { Simó \& Pedrós- } \\
\text { Alió (1999) }\end{array}$ \\
\hline $\begin{array}{l}\text { Dilution } \\
\text { approach }\end{array}$ & $\begin{array}{l}\text { Northern } \\
\text { North Sea }\end{array}$ & $5-10$ & $0.40-1.03$ & $54-121$ & $14.8-45.6$ & $11.4-59.9$ & $\begin{array}{l}\text { Present } \\
\text { study }\end{array}$ \\
\hline
\end{tabular}


during an $\mathrm{SF}_{6}$ Lagrangian experiment in an anticyclonic eddy in the Iceland Basin with surface waters containing numbers of Emiliania huxleyi, levels of DMSPp and chl a concentrations similar to the present study. The consumption rates of total DMSP were calculated from the decrease in total DMSP concentration during dark incubations (Simó \& Pedrós-Alió 1999). These values encompass all processes that involve a DMSP loss, including grazer assimilation, algal and bacterial cleavage, bacterial demethylation and bacterial assimilation. The similar rates of DMSPp consumption between the 2 studies (Table 5) suggests that in waters characterised by low chl a concentrations and abundant E. huxleyi, microzooplankton may be the principal agents of DMSPp transformation. They are likely to assimilate a proportion of the DMSP themselves, provide a supply of dissolved DMSPd which bacteria may metabolise and also possibly produce DMS as a result of the DMSP lyase enzymes of ingested algal cells.

\section{What do $\mu_{\mathrm{dmsp}}$ and $g_{\mathrm{dmsp}}$ represent?}

Although the results of DMSPp production and turnover rates determined by the dilution approach are tenable, it is important to explore what they represent and potential errors in the approach. The determination of DMSP production and turnover by the dilution approach assumes that DMSPp measured on GF/F filters exclusively comprises DMSP within phytoplankton cells. However, bacteria (Diaz et al. 1992), heterotrophic protozoans (Ishida 1996), copepods (Kwint et al. 1996, Tang et al. 1999) and detrital material including copepod faecal pellets (Kwint et al. 1996) may contain DMSP. In an attempt to identify the phytoplankton group-specific sources of DMSPp (Fig. 1), the predicted DMSPp contribution of the phytoplankton accounts for the total DMSPp measured on 3 dates during the Lagrangian period. In contrast, on the remaining dates up to $49 \%$ of the measured DMSPp could not be accounted for (Fig. 1). This suggests that other components of the $<200 \mu \mathrm{m}$ plankton may make up a substantial proportion of the DMSPp. However, it is likely that the taxon-specific DMSP cell content used in the estimates differs from those encountered in natural waters, and this may, in part, account for the shortfall in partitioning total DMSPp. In addition, unidentified components of the phytoplankton may be important contributors to the DMSPp pool, and delicate phytoplankton cells may be lost due to preservation. However, if a large proportion of DMSPp is contained in other particles, then measurements of apparent net change in DMSPp in the dilution experiments may not represent net production of only phytoplankton DMSP, with implications for estimates of instantaneous DMSPp production and turnover.

Few estimates of bacterial DMSPp have been made in natural waters, and it was not measured in the present study. However, the bacterial carbon biomass in surface waters during the Lagrangian experiment averaged $374 \mathrm{nM}$, and bacteria have been found to rapidly consume DMSPd (Zubkov et al. 2001). If bacteria were able to sequester DMSP to the same levels as DMSP-rich phytoplankton (about $10 \%$ of total cell carbon), an upper limit of the bacterial DMSPp contribution would be close to $7 \mathrm{nM}$ or about $10 \%$ of the total DMSPp. These estimates are supported by measurements of DMSP in water collected from the Mediterranean and the tropical North Atlantic, where the contribution of bacteria-sized particles (0.2 to 1.0 and 0.2 to $2.0 \mu \mathrm{m}$, respectively) was approximately $10 \%$ of total DMSPp (Belviso et al. 1993). In dilution experiments, bacterioplankton generally grow faster than cooccurring phytoplankton and are grazed at a correspondingly higher rate (Archer et al. 2001). As a result, de novo synthesis and turnover of phytoplankton DMSPp may be overestimated.

Whether natural populations of microzooplankton, including dinoflagellate taxa, incorporate or synthesise DMSP remains to be discovered. The dinoflagellate Crypthecodinium cohnii, when grown heterotrophically in culture, is able to synthesise DMSP (Uchida et al. 1996). It is possible that microzooplankton represent a sizeable pool of DMSPp. The presence of undegraded pigment sequestered within microzooplankton at the beginning of dilution incubations may cause an underestimate of phytoplankton growth rates based on pigment analyses (Waterhouse \& Welschmeyer 1995). Similarly, DMSP contained in microzooplankton at the start of experiments may lead to an underestimate of apparent phytoplankton DMSP production. Furthermore, the dilution approach relies on the assumption that phytoplankton mortality due to grazing is proportional to the dilution effect on grazer abundance (Landry \& Hassett 1982), and therefore it follows that levels of microzooplankton DMSP would be expected to alter in proportion to the level of dilution. However, if microzooplankton abundance alters disproportionately to the level of dilution (e.g. Dolan et al. 2000), it may have implications on both the estimates of mortality due to grazing and the net DMSPp production rates.

In summary, the largest uncertainty in the estimates of phytoplankton DMSPp production and turnover most likely stems from the influence of other particles that contain DMSP. Bacterial sequestration of DMSP may lead to an overestimation of the apparent DMSPp growth rates and therefore overestimates of $\mu_{\mathrm{dmsp}}$ and possibly $g_{\mathrm{dmsp}}$. Alternatively, if DMSP is contained in microzooplankton or detrital matter at the start of incu- 
bations, apparent phytoplankton DMSP growth rates may be underestimated. Further studies, possibly involving laboratory culture experiments, are required to fully understand the influence of other forms of DMSPp on estimates of net phytoplankton DMSP growth and, hence, to define $\mu_{\mathrm{dmsp}}$ and $g_{\mathrm{dmsp}}$. In the remainder of the discussion, $\mu_{\mathrm{dmsp}}$ and $g_{\mathrm{dmsp}}$ are assumed to represent instantaneous growth and mortality of phytoplankton DMSP.

\section{DMSPp producers and the phytoplankton community}

The rates of DMSPp production calculated from the dilution experiments were found to be closely correlated to estimates of ${ }^{14} \mathrm{C}$ primary production (Fig. 4). Both ${ }^{14} \mathrm{C}$ incorporation rates and the estimates of DMSPp production based on values of $\mu_{\mathrm{dmsp}}$ are likely to underestimate gross production. However, the close coupling between them lends support to the significance of the values of $\mu_{\mathrm{dmsp}}$ and therefore $g_{\mathrm{dmsp}}$ and to the view that DMSPp production is chiefly a product of phytoplankton synthesis. Based on the linear regression between ${ }^{14} \mathrm{C}$ production and DMSPp production (Fig. 4), DMSPp production rates in the 8 dilution experiments are equivalent to $10.8( \pm 2.4 \mathrm{SE}) \%$ of the carbon fixed by phytoplankton. This is consistent with estimates of the contribution of DMSP to cellular carbon of $>10 \%$ in species that produce significant amounts of DMSP (Matrai \& Keller 1994) and reasonable for a phytoplankton community dominated by DMSP-rich phytoplankton. Using the same regression values (Fig. 4), the molar ratio of production of carbon:sulphur was $45.5( \pm 10.3 \mathrm{SE})$, where the sulphur production accounted for is purely in the form of DMSP. This is in good agreement with estimates of the C:S molar ratio of DMSP-rich phytoplankton in culture. The organic C:S molar ratios of cells of 3 DMSP-rich

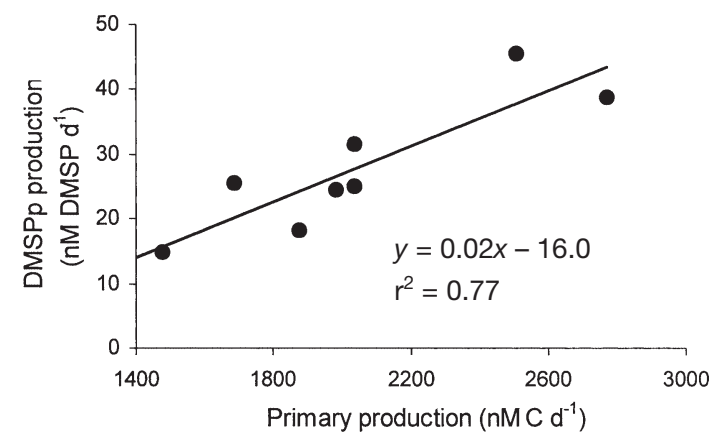

Fig. 4. Relationship between the potential production of DMSPp (Pp, Table 3A) with primary production measured as ${ }^{14} \mathrm{C}$ incorporation (Table 1). Dilution experiments and primary production incubations were carried out using water collected at the same depth and times
phytoplankton-Amphidinium carterae, Prorocentrum minimum and Emiliania huxleyi-in culture were 56, 48 and 80, respectively (Matrai \& Keller 1994). DMSP accounted for the majority (50 to $100 \%$ ) of the particulate organic sulphur in these taxa.

It may be possible to judge how the dynamics of DMSP producing phytoplankton differ from those of the bulk phytoplankton community by comparing estimates of growth and mortality for chl a, Emiliania huxleyi and DMSPp. In general, the rates of turnover of DMSPp and E. huxleyi were similar and lower than for chl a (Table 4, Fig. 3B). This indicates that grazing pressure on DMSPp-containing phytoplankton, including E. huxleyi, was lower than that on the bulk phytoplankton community and may lend support to the suggestion by Wolfe et al. (1997) that DMSP acts as part of a grazing-deterrence mechanism. However, in dilution experiments in which the net production of a variety of phytoplankton pigments is determined, varying degradation rates for different compounds are thought to complicate comparisons of taxon-specific mortality (Waterhouse \& Welshmeyer 1995). If DMSP is sequestered or incompletely degraded by microzooplankton, then turnover rates may be underestimated. Similarly, it could be argued that the higher turnover rates determined for chl a than for DMSPp (Table 4, Fig. 3B) may be the result of more complete chl $a$ degradation during digestion and lower levels of chl a incorporation into microzooplankton cells rather than selectivity against DMSP producing algae. Direct cell counts may be the most accurate measure of net growth and therefore grazing mortality in dilution experiments, although they do not account for changes in cell volume/biomass that may occur as part of the phytoplankton growth (Verity et al. 1996). In the 5 experiments in which the mortality due to grazing on E. huxleyi $\left(g_{\text {Ehux }}\right)$ was determined, it differed significantly from $g_{\mathrm{dmsp}}$ on only 1 occasion and was significantly lower than $g_{\text {chl }}$ on 3 dates (Table 4, Fig. 3B). The similar rates of grazing mortality of E. huxleyi cells and DMSPp are somewhat surprising considering the relatively low proportion of DMSPp contributed by E. huxleyi, the variety of phytoplankton taxa that contributed to the DMSPp pool (see above) and probable variations in DMSP-lyase activity between phytoplankton taxa. They suggest that the grazing pressure on the bulk of the DMSPp-containing phytoplankton population was similar to that on E. huxleyi. Protozoan grazers select prey partly on the basis of size (e.g. Fenchel 1980). The size range of abundant DMSP-containing phytoplankton was known to vary 3 fold, from Prorocentrum minimum (15 $\mu \mathrm{m}$ diameter), which contributed an estimated 0 to $35 \%$ of the DMSPp, to E. huxleyi $(\sim 5 \mu \mathrm{m}$ diameter), and may have been grazed by different taxa of microzooplankton. However, the dominant compo- 
nent of the microzooplankton communities present in the experiments was an oligotrich ciliate resembling Strombidium ovale, $\sim 50 \mu \mathrm{m}$ in length, which alone accounted for 11 to $51 \%$ of the total microzooplankton biomass. It seems likely that the $S$. ovale-type ciliates were capable of ingesting almost the complete size range of DMSP-containing phytoplankton, including E. huxleyi, P. minimum and the other nanophytoplankton that also probably contributed to the DMSPp pool; this may account for the similar turnover rates of DMSPp and E. huxleyi.

It is possible to estimate the contribution of Emiliania huxleyi to the production and consumption of DMSPp based on a constant DMSP content of $1.3 \mathrm{pg} \mathrm{cell}^{-1}$ (see above and Fig. 1). The potential production of DMSPp by E. huxleyi (Table 3C) varied between $25 \%$ of the total DMSPp production on 19 June and $2 \%$ on 28 June. Similarly, the rate of consumption of E. huxleyi represented 6 to $23 \%$ of the total DMSPp consumed. Obviously, other phytoplankton contributed substantially to the DMSPp production and turnover.

\section{Microzooplankton assimilation and transformation of DMSPp}

There is growing evidence that DMSP is of nutritional importance to planktonic heterotrophic organisms. Dissolved DMSP is potentially an important sulphur and carbon source for bacterioplankton (Kiene \& Linn 2000, Zubkov et al. 2001), and dietary DMSP may be incorporated into the tissues of a variety of copepods (Tang et al. 1999). In addition, a large amount of research has focussed on the tissue content of DMSP in seafood (e.g. Iida \& Tokunaga 1986) and use of DMSP as a feeding and/or growth stimulant in cultured fish and shellfish (e.g. Nakajima 1991). DMSP may be an equally important component of microzooplankton diets. If DMSP or DMS are of nutritional value, they may be assimilated by the microzooplankton with a degree of assimilation in part dependent on their carbon and sulphur demands and directly affecting the level of production of DMSPd and/or DMS. The dilution approach has been used to directly quantify the rates of release of DMS and DMSPd from microzooplankton grazers in natural waters (Archer et al. 2001). This approach is not always practicable due to changes in the dissolved pool of DMSPd and DMS that may result from the filtration procedures required for the experiments (Archer et al. 2001). As a more straightforward alternative, it may be possible to estimate the production of dissolved DMS+DMSPd from the levels of ingestion of DMSPp measured in the present study.

Assuming a microzooplankton gross production rate of $0.4 \mathrm{~d}^{-1}$, a gross growth efficiency of 0.3 (Straile 1997), and carbon:sulphur molar ratio of 80, equivalent to DMSP-rich phytoplankton (Matrai \& Keller 1994), it is possible to approximate the microzooplankton carbon and sulphur demands (Table 6). Except on 24 June, when DMSP ingestion rates were exceptionally high relative to microzooplankton biomass (Table 3A), DMSPp possibly contributed 2 to $3 \%$ of the microzooplankton carbon requirements and 26 to $44 \%$ of their sulphur demand (Table 6). A key value in these calculations is the DMSPp assimilation efficiency, as it has a direct bearing on the quantity of DMSP and DMS released into solution. A gross growth efficiency of 0.3 implies the release of $70 \%$ of ingested DMSPp either as DMSP in faecal pellets, DMSPd, DMS and acrylate or alternative by-products of digestion. Several laboratory studies suggest this level of release may be a fair approximation. More than $66 \%$ of ingested DMSP contained in the prymnesiophyte Isochrysis galbana was released to solution when consumed by the ciliate

Table 6. The potential contribution of DMSPp to carbon and sulphur demands of microzooplankton (MZP) and the quantity of DMSPp potentially released to solution as DMSPd or DMS. The ingested carbon and sulphur demands of MZP are based on a specific growth rate of $0.4 \mathrm{~d}^{-1}$ and a gross growth efficiency of 0.3 . An MZP carbon:sulphur molar ratio of 80 was assumed to calculate sulphur demand (see text for further details)

\begin{tabular}{|c|c|c|c|c|c|c|}
\hline $\begin{array}{l}\text { Day in } \\
\text { June }\end{array}$ & $\begin{array}{c}\text { Ingested carbon } \\
\text { demand } \\
\left(\mu \mathrm{C} \mathrm{C}^{-1} \mathrm{~d}^{-1}\right)\end{array}$ & $\begin{array}{l}\text { Ingested sulphur } \\
\text { demand } \\
\left(\mu \mathrm{S} \mathrm{S} \mathrm{l}^{-1} \mathrm{~d}^{-1}\right)\end{array}$ & $\begin{array}{l}\text { DMSPp contribution } \\
\text { to carbon demand } \\
(\%)\end{array}$ & $\begin{array}{l}\text { DMSPp contribution } \\
\text { to sulphur demand } \\
\qquad(\%)\end{array}$ & $\begin{array}{l}{ }^{' D M S P} \\
\text { released } \\
\left(\mathrm{nM} \mathrm{d}^{-1}\right)\end{array}$ & $\begin{array}{c}\text { MZP biomass-specific } \\
\text { 'DMSP' release } \\
\left(\mathrm{nM} \mu \mathrm{g} \mathrm{C} \mathrm{C}^{-1} \mathrm{~d}^{-1}\right)\end{array}$ \\
\hline 18 & 42 & 1.4 & 2 & 26 & 8.0 & 0.31 \\
\hline 19 & 46 & 1.5 & 3 & 44 & 14.7 & 0.52 \\
\hline 21 & 67 & 2.2 & 2 & 37 & 17.9 & 0.44 \\
\hline 22 & 62 & 2.1 & 2 & 30 & 13.4 & 0.36 \\
\hline 24 & 51 & 1.7 & 7 & 113 & 41.9 & 1.35 \\
\hline 26 & 53 & 1.8 & 2 & 33 & 12.8 & 0.40 \\
\hline 27 & 80 & 2.7 & 2 & 30 & 17.6 & 0.36 \\
\hline 28 & 93 & 3.1 & 3 & 41 & 28.1 & 0.49 \\
\hline
\end{tabular}


Strombidium sulcatum (Christaki et al. 1996). Wolfe et al. (1997) found that the DMSP-lyase activity of ingested E. huxleyi affected the level of production of DMS when ingested by the dinoflagellate Oxyrrhis marina. When strains with high lyase activity were consumed, approximately $60 \%$ of ingested DMSPp was converted to DMS. If in the present study $70 \%$ of ingested DMSPp was released to solution, then DMSPd+DMS production due to microzooplankton grazing would amount to 8.0 to $41.9 \mathrm{nM} \mathrm{d}^{-1}$ (Table 6). This is equivalent to a microzooplankton biomass specific production of 0.31 to $0.52 \mathrm{nM} \mathrm{S} \mu \mathrm{g} \mathrm{C}^{-1} \mathrm{~d}^{-1}$ in 7 of the experiments and $1.35 \mathrm{nM} \mathrm{S} \mu \mathrm{C} \mathrm{C}^{-1} \mathrm{~d}^{-1}$ on 24 June (Table 6). Comparable values of 0.39 to $0.65 \mathrm{nM} \mathrm{S} \mu \mathrm{g}$ $\mathrm{C}^{-1} \mathrm{~d}^{-1}$ were determined by using the dilution approach to directly estimate DMS+DMSPd production rates in waters of the Iceland Basin (Archer et al. 2001). Phytoplankton and microzooplankton communities were similar to the present study, with concentrations of DMSPp, chl a and microzooplankton biomass of 93 to $125 \mathrm{nM} 1.4 \mu \mathrm{g} \mathrm{l}^{-1}$ and 21.9 to $25.3 \mu \mathrm{g} \mathrm{C} \mathrm{^{-1 }}$, respectively. This suggests that in DMSP-rich, nanophytoplankton-dominated waters, the role of microzooplankton in transforming DMSPp to solution may be predicted on the basis of microzooplankton biomass.

\section{Conclusions}

The standing stocks of DMSPp in the undiluted waters used for dilution experiments averaged $77 \mathrm{nM}$, with DMSPp production levels of $39 \% \mathrm{~d}^{-1}$ of the standing stocks closely matched by microzooplankton ingestion rates (Fig. 5). The ambient concentrations of

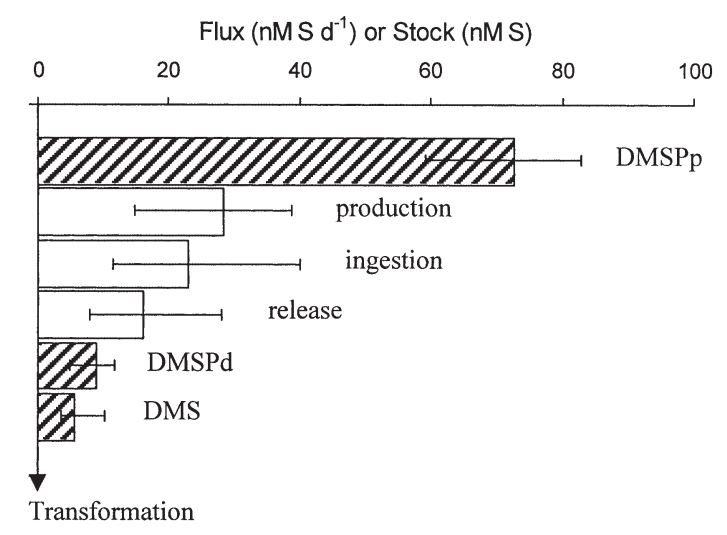

Fig. 5. Average values of the stocks of DMSPp, DMSPd and DMS and the rates of DMSPp production, ingestion by microzooplankton and potential release to solution determined in 7 dilution experiments. The bars show the range of values measured. Values are not included from the experiment on 24 June when both DMSPp concentration and DMSPp consumption were more than $3 \times$ SD greater than the mean values
DMSPd and DMS in the water at the start of dilution experiments were 4.9 to 11.6 and 3.7 to $10.1 \mathrm{nM}$, respectively (Table 2). The level of release of the equivalent of 8.0 to $41.9 \mathrm{nM} \mathrm{d}^{-1}$ of DMSPp following digestion (Table 6) suggests that microzooplankton grazing transforms sufficient DMSPp to solution to support a daily turnover of the DMSPd and DMS stocks (Fig. 5). In order to improve predictive models of DMS production, it would be useful to address the degree of assimilation of DMSP and DMS by microzooplankton and the factors that influence this in natural waters. These results illustrate the value of the dilution approach for examining the initial stages in the complex network of processes that lead to DMS production. For a more complete understanding of these processes, the approach needs to be applied to the various planktonic environments considered to be important producers of DMS. The approach may also be applicable to elucidating the production and fate of other key phytoplankton metabolites.

Acknowledgements. We wish to thank the captain and crew of the RRS 'Discovery' during cruise D241. We acknowledge the considerable help of fellow scientists during the cruise, in particular P. Nightingale, M. Liddicoat and R. Ling for providing the Lagrangian component to the study, and we thank S. Lavender (RSDAS, PML) for the remote sensing information and $M$. Zubkov for advice on the manuscript. The research was supported by funding from the UK Defence Evaluation and Research Agency (DERA/SESS/C21.10.2) and forms part of the PML Biogeochemistry programme.

\section{LITERATURE CITED}

Andersen T, Schartau AKL, Paasche E (1991) Quantifying external and internal nitrogen and phosphorous pools, as well as nitrogen and phosphorus supplied through remineralisation, in coastal marine plankton by means of a dilution technique. Mar Ecol Prog Ser 69:67-80

Andreae MO, Crutzen PJ (1997) Atmospheric aerosols: biogeochemical sources and role in atmospheric chemistry. Science 276:1052-1058

Archer SD, Stelfox-Widdicombe CE, Burkill PH, Malin G (2001) A dilution approach to quantify the production of dissolved dimethylsulphoniopropionate and dimethyl sulphide due to microzooplankton herbivory. Aquat Microb Ecol 22(1):27-41

Ayers GP, Gras JL (1991) Seasonal relationship between cloud condensation nuclei and aerosol methanesulphonate in marine air. Nature 353:834-835

Barnard WR, Andreae MO, Iverson RL (1984) Dimethylsulfide and Phaeocystis pouchetii in southeastern Bering Sea. Cont Shelf Res 3:103-113

Bates TS, Kiene RP, Wolfe GV, Matrai PA, Chavez FP, Buck KR, Blomquist BW, Cuhel RL (1994) The cycling of sulfur in surface seawater of the northeast Pacific. J Geophys Res 99:7835-7843

Belviso S, Kim SK, Rassoulzadegan F, Krajka B, Nguyen BC, Mihalopoulos N, Buat-Menard P (1990) Production of 
dimethylsulphonium propionate (DMSP) and dimethyl sulfide (DMS) by a microbial food web. Limno Oceanogr 8: 1810-1821

Belviso S, Christaki U, Vidussi F, Marty JC, Vila M, Delgado M (1993) Size distribution of dimethylsulfoniopropionate (DMSP) in areas of the tropical northeastern Atlantic Ocean and the Mediterranean Sea. Mar Chem 44:55-71

Bratbak G, Wilson W, Heldal M (1996) Viral control of Emiliania huxleyi blooms? J Mar Syst 9:75-81

Burkill PH, Mantoura RFC, Llewellyn CA, Owens NJP (1987) Microzooplankton grazing and selectivity of phytoplankton in coastal waters. Mar Biol 93:581-590

Burkill PH, Edwards ES, John AWG, Sleigh MA (1993) Microzooplankton and their herbivorous activity in the northeastern Atlantic Ocean. Deep-Sea Res 40:479-493

Charlson RJ, Lovelock JE, Andreae MO, Warren SG (1987) Oceanic phytoplankton, atmospheric sulfur, cloud albedo and climate. Nature 326:655-661

Christaki U, Belviso S, Dolan JR, Corn M (1996) Assessment of the role of copepods and ciliates in the release to solution of particulate DMSP. Mar Ecol Prog Ser 141:119-127

Corn M, Belviso S, Partensky F, Simon N, Christaki U (1996) Origin and importance of picoplanktonic DMSP. In: Kiene RP, Visscher PT, Keller MD, Kirst GO (eds) Biological and environmental chemistry of DMSP and related sulfonium compounds. Plenum Press, New York, p 191-201

Dacey JWH, Wakeham SG (1986) Oceanic dimethylsulfide: production during zooplankton grazing on phytoplankton. Science 233:1314-1316

Dacey JWH, Howse FA, Michaels AF, Wakeham SG (1998) Temporal variability of dimethylsulfide and dimethysulfoniopropionate in the Sargasso Sea. Deep-Sea Res I 45: 2085-2104

Daly KL, DiTullio GR (1996) Particulate dimethylsulfoniopropionate removal and dimethylsulfide production by zooplankton in the Southern Ocean. In: Kiene RP, Visscher PT, Keller MD, Kirst GO (eds) Biological and environmental chemistry of DMSP and related sulfonium compounds. Plenum Press, New York, p 223-238

Diaz MR, Visscher PT, Taylor BF (1992) Metabolism of dimethylsulfoniopropionate and glycine betaine by a marine bacterium. FEMS Microb Lett 96:61-66

Dickson DM, Kirst GO (1987a) Osmotic adjustment in marine eukaryotic algae: the role of inorganic ions, quaternary ammonium, tertiary sulphonium and carbohydrate solutes. I. Diatoms and a rhodophyte. New Phytol 106: 645-655

Dickson DM, Kirst GO (1987b) Osmotic adjustment in marine eukaryotic algae: the role of inorganic ions, quaternary ammonium, tertiary sulphonium and carbohydrate solutes. II. Prasinophytes and haptophytes. New Phytol 106:645-655

Dolan JR, Gallegos CL, Moigis A (2000) Dilution effects on microzooplankton in dilution grazing experiments. Mar Ecol Prog Ser 200:127-139

Gabric A, Murray N, Stone L, Kohl M (1993) Modelling the production of dimethylsulfide during a phytoplankton bloom. J Geophys Res 98(C12):22805-22816

Gage DA, Rhodes D, Nolte KD, Hicks WA, Leustek T, Cooper AJL, Hanson AD (1997) A new route for synthesis of dimethylsulphoniopropionate in marine algae. Nature 387:891-894

Gifford DJ (1988) Impact of grazing by microzooplankton in the northwest arm of Halifax Harbour, Nova Scotia. Mar Ecol Prog Ser 47:249-258

Hill RW, White BA, Cotrell MT, Dacey JWH (1998) Virusmediated total release of dimethylsulfoniopropionate from marine phytoplankton: a potential climate process. Aquat Microb Ecol 14:1-6

Holligan PM, Turner SM, Liss PS (1987) Measurement of dimethyl sulphide in frontal regions. Cont Shelf Res 7: 213-224

Holligan PM, Fernandez E, Aiken J, Balsh WM, Boyd $\mathrm{P}$, Burkill PH, Finch M, Groom SB, Malin G, Muller K, Purdie DA, Robinson C, Trees CC, Turner SM, van der Wal P (1993) A biogeographic study of the coccolithophore, Emiliania huxleyi, in the North Atlantic. Global Biogeochem Cycles 7:879-900

Iida H, Tokunaga T (1986) Dimethyl sulphide and dimethylbeta-propiothetin in shellfish. Bull Jpn Soc Sci Fish Nissuishi 52:557-563

Ishida Y (1996) 30 years of research on dimethylsulfoniopropionate. In: Kiene RP, Visscher PT, Keller MD, Kirst GO (eds) Biological and environmental chemistry of DMSP and related sulfonium compounds. Plenum Press, New York, p 1-12

Karsten U, Wiencke C, Kirst GO (1992) Dimethylsulphoniopropionate (DMSP) accumulation in green macroalgae from polar to temperate regions: interactive effects of light versus salinity and light versus temperature. Polar Biol 12: 603-607

Kates M, Volcani BE (1996) Biosynthetic pathways for phosphatidylsulfocholine, the sulfonium analogue of phosphatidylcholine, in diatoms. In: Kiene RP, Visscher PT, Keller MD, Kirst GO (eds) Biological and environmental chemistry of DMSP and related sulfonium compounds. Plenum Press, New York, p 109-120

Keller MD, Bellows WK, Guillard RRL (1989) A survey of dimethylsulfide production in 12 classes of marine phytoplankton. In: Saltzman ES, Cooper JW (eds) Biogenic sulfur in the environment. Am Chem Soc Symp Ser 393: 167-182

Kiene RP, Linn LJ (2000) Distribution and turnover of dissolved DMSP and its relationship with bacterial production and dimethyl sulphide in the Gulf of Mexico. Limnol Oceanogr 45:849-861

Kirst GO (1996) Osmotic adjustment in phytoplankton and macroalgae. The use of dimethylsulfoniopropionate (DMSP). In: Kiene RP, Visscher PT, Keller MD, Kirst GO (eds) Biological and environmental chemistry of DMSP and related sulfonium compounds. Plenum Press, New York, p 121-129

Kirst GO, Thiel C, Wolff H, Nothnagel J, Wanzek M, Ulmke R (1991) Dimethylsulphoniopropionate (DMSP) in ice algae and its possible role. Mar Chem 35:381-388

Kovala PE, Larrance JD (1966) Comparison of phytoplankton cell numbers, cell volume, cell surface and plasma volume, per metre, from microscopic counts. Univ Wash Spec Rep 36:1-21

Kwint RLJ, Irigoien X, Kramer KJM (1996) Copepods and DMSP. In: Kiene RP, Visscher PT, Keller MD, Kirst GO (eds) Biological and environmental chemistry of DMSP and related sulfonium compounds. Plenum Press, New York, p 239-252

Landry MR, Hassett RP (1982) Estimating the grazing impact of marine microzooplankton. Mar Biol 67:283-288

Landry MR, Haas LW, Fagerness VL (1984) Dynamics of microbial plankton communities: experiments in Kaneohe Bay, Hawaii. Mar Ecol Prog Ser 16:127-133

Landry MR, Kirshtein J, Constantinou J (1995a) A refined dilution technique for measuring the community grazing impact of microzooplankton, with experimental test in the central equatorial Pacific. Mar Ecol Prog Ser 120: $53-63$ 
Landry MR, Constantinou J, Kirshtein J (1995b) Microzooplankton grazing in the central equatorial Pacific during February and August 1992. Deep-Sea Res II 42:657-671

Laroche D, Vézina AF, Levasseur M, Gosselin M, Stefels J, Keller MD, Matrai PA, Kwint RLJ (1999) DMSP synthesis and exudation in phytoplankton: a modeling approach. Mar Ecol Prog Ser 180:37-49

Latasa M, Landry MR, Schlüter L, Bidigare RR (1997) Pigment-specific growth and grazing rates of phytoplankton in the central equatorial Pacific. Limnol Oceanogr 42: 289-298

Law CS, Watson AJ, Liddicoat MI, Stanton T (1998) Sulphur hexafluoride as a tracer of biogeochemical and physical processes in an open-ocean iron fertilisation experiment. Deep-Sea Res II 45:977-994

Leck C, Larrson U, Bagander LE, Johansson S, Hajdu S (1990) Dimethyl sulfide in the Baltic Sea: annual variability in relation to biological activity. J Geophys Res 95: 3353-3363

Lehrter JC, Pennock JR, McManus GB (1999) Microzooplankton grazing and nitrogen excretion across a surface estuarine-coastal interface. Estuaries 22:113-125

Lessard EJ (1991) The trophic role of heterotrophic dinoflagellates in diverse marine environments. Mar Microb Food Webs 5:49-58

Lessard EJ, Swift E (1986) Dinoflagellates from the North Atlantic classified as phototrophic or heterotorphic by epifluorescence microscopy. J Plankton Res 8:1209-1215

Liss PS, Hatton AD, Malin G, Nightingale PD, Turner SM (1997) Marine sulphur emissions. Philos Trans R Soc Lond B 352:159-169

Malin G, Turner SM, Liss PS, Holligan PM, Harbour DS (1993) Dimethyl sulfide and dimethylsulfoniopropionate in the Northeast Atlantic during the summer coccolithophore bloom. Deep-Sea Res 40:1487-1508

Malin G, Liss PS, Turner SM (1994) Dimethyl sulphide: production and atmospheric consequences. In: Green JC, Leadbeater BSC (eds) The haptophyte algae. Systematics Association Special Volume No. 51. Clarendon Press, Oxford, p 303-320

Malin G, Wilson WH, Bratbak G, Liss PS, Mann NH (1998) Elevated production of dimethyl sulfide resulting from viral infection of cultures of Phaeocystis pouchetii. Limnol Oceanogr 43:1389-1393

Matrai PA, Keller MD (1993) Dimethylsulfide in a large-scale coccolithophore bloom in the Gulf of Maine. Cont Shelf Res 13:831-843

Matrai PA, Keller MD (1994) Total organic sulfur and dimethylsulfoniopropionate in marine phytoplankton: intracellular variations. Mar Biol 119:61-68

Nakajima K (1991) Dimethyl-beta-propiothetin, a potent growth and moult stimulant for striped prawn. Nippon Suisan Gakkaishi Bull Jpn Soc Sci Fish 57:1717-1722

Neuer S, Franks PJS (1993) Determination of ammonium uptake and regeneration rates using the seawater dilution method. Mar Biol 116:497-505

Nguyen BC, Belviso S, Mihalopoulos N (1988) Dimethyl sulfide production during natural phytoplanktonic blooms. Mar Chem 24:133-141

Nightingale PA, Malin G, Law CS, Watson AJ, Liddicoat MI, Boutin J, Upstill-Goddard RC (2000) In-situ evaluation of air-sea gas exchange parameterisations using novel conservative and volatile tracers. Global Biogeochem Cycles 14:373-387

Osinga R, Minnaard JJ, Lewis WE, van Duyl FC (1996) Production of dimethylsulfide after deposition of increasing amounts of Emiliania huxleyi onto sediments in marine microcosms. In: Kiene RP, Visscher PT, Keller MD, Kirst GO (eds) Biological and environmental chemistry of DMSP and related sulfonium compounds. Plenum Press, New York, p 381-390

Putt M, Stoecker DK (1989) An experimentally determined carbon:volume ratio for marine 'oligotrichous' ciliates from estuarine and coastal waters. Limnol Oceanogr 34: 1097-1103

Simó R, Pedrós-Alió C (1999) Short-term variability in the open ocean cycle of dimethylsulfide. Global Biogeochem Cycles 13:1173-1181

Sokal RR, Rohlf FJ (1995) Biometry, 3rd edn. Freeman and Company, New York

Stefels J (2000) Physiological aspects of the production and conversion of DMSP in marine algae and higher plants. J Sea Res 43:183-198

Straile D (1997) Gross growth efficiencies of protozoan and metazoan zooplankton and their dependence on food concentration, predator-prey weight ratio, and taxonomic group. Limnol Oceanogr 42:1375-1385

Strom SL, Welshmeyer NA (1991) Pigment-specific rates of phytoplankton growth and microzooplankton grazing in the open subarctic Pacific Ocean. Limnol Oceanogr 36: $50-63$

Tang KW, Dam HG, Visscher PT, Fenn TD (1999) Dimethylsulponiopropionte in marine copepods and its relation to diet and salinity. Mar Ecol Prog Ser 179:771-793

Tarran GA, Zubkov MV, Sleigh MA, Burkill PH, Yallop M (2001) Microbial community structure and standing stocks in the NE Atlantic in June and July 1996. Deep-Sea Res II 48:963-986

Trevena AJ, Jones GB, Wright SW, van den Enden RL (2000) Profiles of DMSP, algal pigments, nutrient and salinity in pack ice from eastern Antarctica. J Sea Res 43:265-274

Turner SM, Malin G, Liss PS, Harbour DS, Holligan PM (1988) The seasonal variation of dimethyl sulphide and dimethylsulfoniopropionate in nearshore waters. Limnol Oceanogr 33:364-375

Turner SM, Malin G, Bagander LE, Leck C (1990) Interlaboratory calibration and sample analysis of dimethyl sulfide in water. Mar Chem 29:47-62

Turner SM, Malin G, Nightingale PD, Liss PS (1996) Seasonal variation of dimethyl sulfide in the North Sea and an assessment of fluxes to the atmosphere. Mar Chem 54: 245-262

Uchida A, Ooguri T, Ishida T, Kitaguchi H, Ishida Y (1996) Biosynthesis of dimethylsulfoniopropionate in Crypthecodinium cohnii (Dinophyceae). In: Kiene RP, Visscher PT, Keller MD, Kirst GO (eds) Biological and environmental chemistry of DMSP and related sulfonium compounds. Plenum Press, New York, p 97-108

van den Berg AJ, Turner SM, van Duyl FC, Ruardij P (1996) Model structure and analysis of dimethylsulphide (DMS) production in the southern North Sea, considering phytoplankton dimethylsulphoniopropionate-(DMSP) lyase and eutrophication effects. Mar Ecol Prog Ser 145:233-244

Verity PG, Stoecker DK, Sieracki ME, Nelson JR (1996) Microzooplankton grazing of primary production at $140^{\circ}$ W in the equatorial Pacific. Deep-Sea Res 43:1227-1255

Viaravamurthy A, Andreae MO, Iverson RL (1985) Biosynthesis of dimethyl sulfide and dimethylpropiothetin by Hymenomonas carterae in relation to sulphur source and salinity variations. Limnol Oceanogr 30:59-70

Waterhouse TY, Welschmeyer NA (1995) Taxon-specific analysis of microplankton grazing rates and phytoplankton growth rates. Limnol Oceanogr 40:827-834

Wolfe GV, Steinke M (1996) Grazing-activated production of 
dimethyl sulfide (DMS) by two clones of Emiliania huxleyi. Limnol Oceanogr 41:1151-1160

Wolfe GV, Sherr EB, Sherr BF (1994) Release and consumption of DMSP from Emiliania huxleyi during grazing by Oxyrrhis marina. Mar Ecol Prog Ser 111:111-119

Wolfe GV, Steinke M, Kirst GO (1997) Grazing-activated chemical defense in a unicellular marine alga. Nature 387: 894-897

Editorial responsibility: John Dolan, Villefranche-sur-Mer, France
Wolfe GV, Levasseur M, Cantin G, Michaud S (2000) DMSP and DMS dynamics and microzooplankton grazing in the Labrador Sea: application of the dilution technique. DeepSea Res 47:2243-2264

Zubkov MV, Fuchs BM, Archer SD, Kiene RP, Amann R, Burkill PH (2001) Linking the composition of bacterioplankton to rapid turnover of dissolved DMSP in an algal bloom in the North Sea. Environ Microb 3:304-311

Submitted: March 2, 2001; Accepted: May 2, 2001

Proofs received from author(s): July 10, 2001 